\title{
Working
}

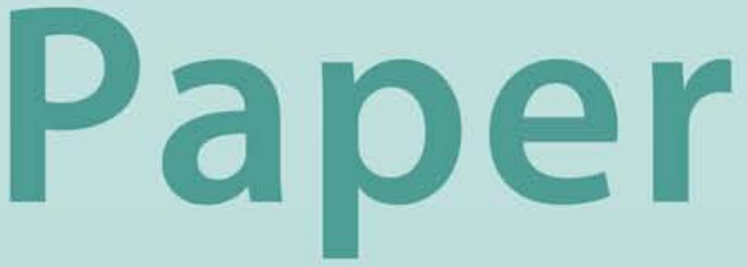




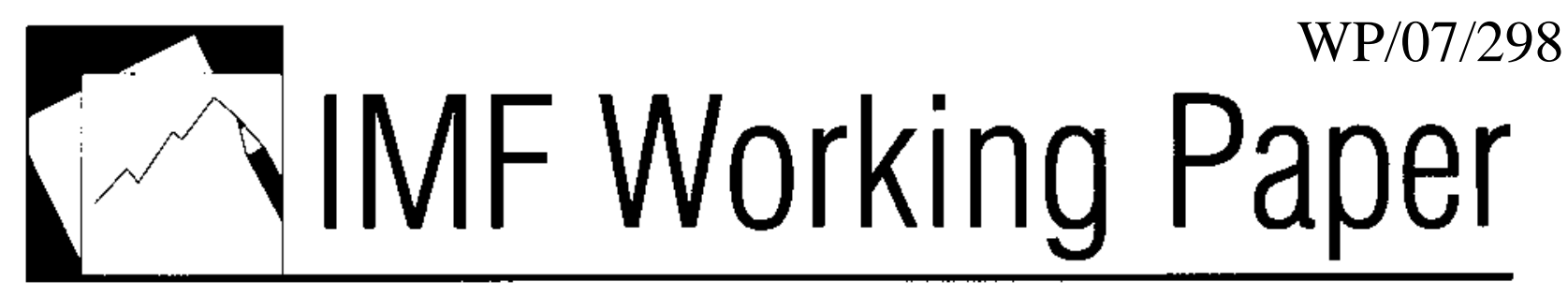

How Has The Globalization of Labor Affected the Labor Income Share in Advanced Countries?

Florence Jaumotte and Irina Tytell 


\title{
IMF Working Paper
}

Research Department

\section{How Has The Globalization of Labor Affected the Labor Share in Advanced Countries?}

\section{Prepared by Florence Jaumotte and Irina Tytell ${ }^{1}$}

Authorized for distribution by Tim Callen

December 2007

\begin{abstract}

\section{This Working Paper should not be reported as representing the views of the IMF.}

The views expressed in this Working Paper are those of the author(s) and do not necessarily represent those of the IMF or IMF policy. Working Papers describe research in progress by the author(s) and are published to elicit comments and to further debate.
\end{abstract}

Labor markets around the world have become increasingly integrated over the last two decades, with the entry of China, India and the former Eastern bloc into the world trading system, the removal of restrictions on trade and capital flows, and rapid technological progress. At the same time, the share of labor in national income decreased in most advanced countries. This paper uses a labor share equation derived from a translog revenue function to estimate the contributions of globalization, technological progress, and labor market policies to the decline in the labor share. The results, obtained for 18 advanced countries over 19822002, suggest that globalization was only one of several factors that have affected the labor share. Technological progress, especially in the information and communications sectors, has had a bigger impact, particularly on the labor share in unskilled sectors.

JEL Classification Numbers:E25, F15, F16, F22, J3

Keywords: Globalization, offshoring, outsourcing, international trade, immigration, information technology, labor, labor share, skills, translog revenue function

Author’s E-Mail Address: fjaumotte@imf.org, itytell@imf.org

\footnotetext{
${ }^{1}$ We thank Robert Feenstra for his guidance and insightful comments. We are also indebted to Christian de Guzman and Stephanie Denis for excellent research assistance.
} 


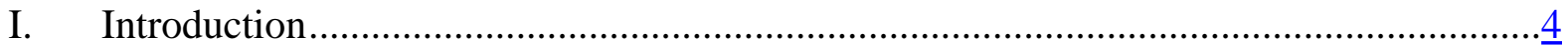

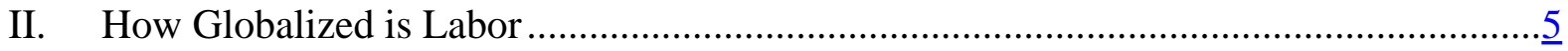

III. How Has The Globalization of Labor Affected Workers in Advanced Economies? ....... 7

IV. Labor Share and the Globalization of Labor: An Empirical Examination ....................10

A. Explaining the Labor Share..........................................................................

B. Empirical Methodology............................................................................. 11

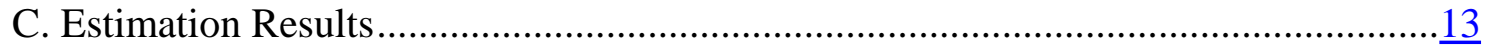

V. The Story Behind the Decline of the Labor Share .................................................15

VI. Labor Compensation Per Worker, Employment, and Labor Globalization:

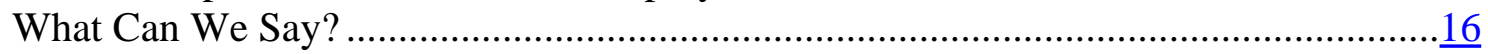

VII. Summary and Policy Implications ..............................................................18

Appendix

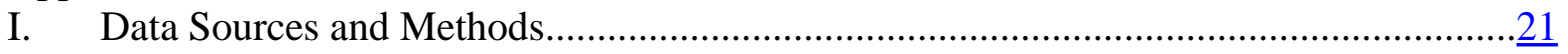

II. Derivation of the Empirical Model ....................................................................

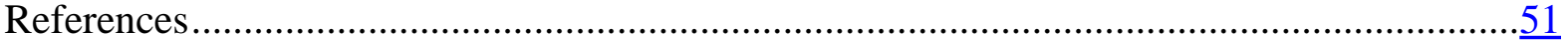

Tables

1. Impact of Labor Globalization and Technological Change on Labor Shares:

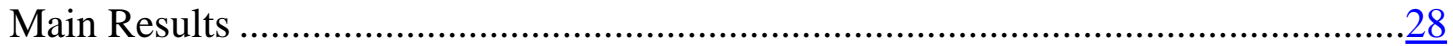

2. Impact of Labor Globalization and Technological Change on Labor Shares:

Alternative Specifications ................................................................................29

3. Impact of Labor Globalization and Technological Change on Skilled and

Unskilled Labor Shares................................................................................

4. Classification of Sectors by Skill Intensity ....................................................................

Figures

1. Alternative Measures of Global Labor Supply ...........................................................

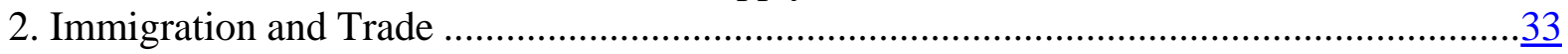

3. Change in the Share of Foreign Labor Force in Total Labor Force by Skill Level,

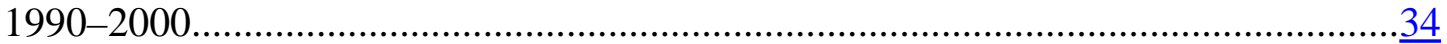

4. Share of Developing Countries in Trade ...................................................................

5. Developing Countries: Exports of Skilled Manufacturing Goods and Services.................... $\underline{36}$

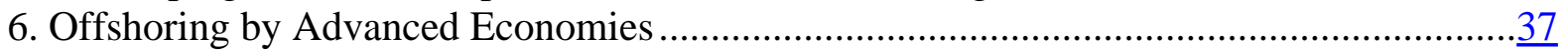

7. Advanced Economies: Offshoring by Category of Inputs ............................................

8. Advanced Economies: Labor Income Shares ..................................................................

9. Advanced Economies: Labor Compensation and Employment .......................................

10. Advanced Economies: Labor Compensation and Employment in Skilled and

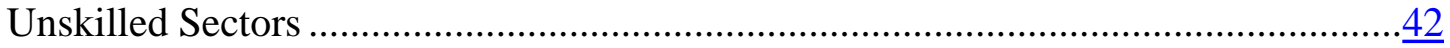

11. Catch-Up by Emerging Markets’ Manufacturing Wages .............................................. 43 
12. Information and Communications Technology (ICT) Capital, Patents, and Labor Market Indicators …………………………………...................................44

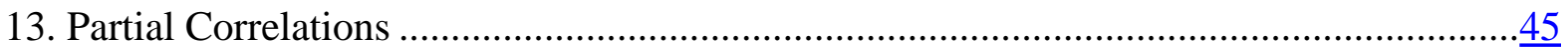

14a. Explaining the Annual Change in the Labor Share.........................................................46

14b. Decomposition of Labor Globalization Effects on the Labor Share.................................. 47

15. Explaining the Annual Change in the Labor Share by Skill Level.....................................48

16. Effect of Changes in Trade Prices on Labor Compensation per Worker and Employment.

17. Advanced Economies' Labor Income Share, Labor Compensation, and

Employment: Robustness to Alternative Skill Classification.... 


\section{INTRODUCTION}

Over the past two decades, labor markets around the world have become increasingly integrated. Political changes and economic reforms have transformed China, India, and the former Eastern bloc countries, effectively involving their large labor forces in open market economies. At the same time, the development of technology, combined with the progressive removal of restrictions on cross-border trade and capital flows, has made it possible for production processes to be unbundled and located further from target markets for a growing universe of goods and services. The location of production has become much more responsive to relative labor costs across countries. There have also been increasing flows of migrants across borders, through both legal and informal routes.

This ongoing globalization of the labor market has drawn increasing attention from policymakers and the media, particularly in the advanced economies. The most asked question is whether the addition of this unprecedentedly large pool of labor from emerging market and developing countries is adversely affecting compensation and employment in the advanced economies.

This paper addresses this important and emotive question. In contrast with most previous studies, which focus on one country or a single channel of transmission, it takes a broad approach, considering a large sample of advanced economies and a full range of transmission channels (competing imports of final goods, offshoring of intermediate products, and immigration). The paper focuses on the following issues:

- How rapidly has the global labor supply grown, and which channels of labor globalization have been most important?

- $\quad$ To what extent can recent trends in labor shares and labor compensation in advanced economies be explained by the changing global labor supply relative to other factors such as technological change and labor market reform? Has the impact been different in skilled and unskilled sectors?

- What policies can help the advanced economies meet the challenges of further labor market globalization?

This paper finds that the effective global labor force has risen fourfold over the last two decades. This growing pool of global labor is being accessed by advanced economies through various channels, including imports of final goods, offshoring of the production of intermediates, and immigration. The decline in traded goods prices resulting from the ongoing globalization of labor has contributed to rising real labor compensation in advanced economies by boosting productivity and output, while emerging market countries have also benefited from rising real wages. Nevertheless, globalization is one of several factors that have acted to reduce the share of income accruing to labor in advanced economies, although rapid technological change has had a bigger impact, especially on workers in unskilled sectors. The analysis finds that countries that have enacted reforms to lower the cost of labor to business and improve labor market flexibility have generally experienced a smaller decline 
in the labor income share. Looking ahead, it is important for countries to maximize the benefits from labor globalization and technological change, while also working to address the distributional impact. To this end, policies should seek to improve the functioning of labor markets; strengthen access to education and training; and ensure adequate social safety nets that cushion the impact on those adversely affected, without obstructing the process of adjustment.

\section{HOW GLOBALIZED IS LABOR?}

A first question to address is how the opening up of China, India, and the former Eastern bloc countries, together with ongoing demographic developments, have affected the global labor supply. This is not easy to answer because much depends on the assumptions made about how much of a country's labor force is in, or could potentially compete in, the global market. One simple approach is to weigh each country's labor force by its export-to-GDP ratio. ${ }^{2}$ By this measure, the effective global labor supply quadrupled between 1980 and 2005, with most of the increase taking place after 1990 (Figure 1). ${ }^{3}$ East Asia contributed about half of the increase, due to a marked rise in working-age population and rising trade openness, while South Asia and the former Eastern bloc countries accounted for smaller increases. While most of the absolute increase in the global labor supply consisted of less-educated workers (defined as those without higher education), the relative supply of workers with higher education increased by about 50 percent over the last 25 years, owing mostly to advanced economies, but also to China.

Advanced economies can access this increased pool of global labor both through imports of goods and services and through immigration. Trade has been the more important channel and has grown more rapidly, not least because immigration remains highly restricted in most countries (Figure 2). A similar picture emerges for developing and emerging market countries, where the export-to-GDP ratio is in general much higher than the ratio of emigrants to the domestic labor force. ${ }^{4}$ Nevertheless, immigration has expanded significantly over the last two decades in some large European economies (Germany, Italy, and the United Kingdom) and in the United States. The share of immigrants in the U.S. labor force is now close to 15 percent and hence comparable to the share of imports in GDP. Elsewhere the share of immigrants is still substantially less than the share of imports in GDP, but it is not negligible. Interestingly, the increase in the share of immigrants over the last ten years was driven mostly by foreigners with tertiary education or at least secondary education (Figure 3).

\footnotetext{
${ }^{2}$ This approach, which follows Harrigan and Balaban (1999), is more accurate for developing countries specialized in labor-intensive activities than for advanced economies whose exports are relatively capital intensive. In order to capture the export of labor through emigration, emigration weights could be added to the trade weights. However, these weights are generally very small.

${ }^{3}$ This compares to estimates in Freeman (2006) that the integration of China, India, and the former Eastern bloc countries doubled the number of workers in the global economy. The difference is due to the weighing of national labor forces by export-to-GDP ratios in this paper's estimates.

${ }^{4}$ The stock of emigrants is limited to those emigrating to OECD economies.
} 
Focusing on trade, the share of developing country products in the imports of advanced economies has doubled since the early 1990s (Figure 4). This owes much to China. Developing countries have also been capturing an increasing share of world markets. At the aggregate level, however, trade is a win-win game. As China, India, and the Eastern bloc countries have opened up, world markets and opportunities to export have expanded considerably for advanced economies and developing countries alike. Developing countries' imports have been growing faster than those of advanced economies and the share of advanced economies' exports going to developing countries has been on the rise (though not as rapidly as the share of developing countries in their own imports). Further, while both import and export prices have been on a declining trend relative to output prices, the terms of trade of advanced economies have improved, by a cumulative 7 percent since 1980. Most notably, there was a substantial improvement in the terms of trade of Japan in the first half of the 1980s. However, the large fall in import prices at this time was mainly the result of the strong appreciation of the yen at a time when oil prices were falling, and was not directly related to globalization.

As can be seen in Figure 5, the strong export dynamism of emerging market and developing countries is in skilled as well as unskilled products: developing countries' share in world exports of skilled goods and services has been on the rise in recent years. ${ }^{5}$ China has led the way, reflecting its very strong growth and a move toward more skill-intensive goods in its export basket. India's export basket is also changing rapidly toward skill-intensive services, but the country's weight in world trade remains small.

One category of trade that has received much attention in recent years is trade in intermediates. The reduction of barriers to cross-border trade and capital flows, combined with technological progress in transport and communication, has made it easier for firms to move parts of their production to less costly foreign locations-a process referred to as offshore outsourcing or, more simply, offshoring. Nevertheless, and contrary to some popular perceptions, offshored inputs, which account for about half of total imports (the rest being imports of final products), have grown somewhat more slowly than total trade (see also OECD, 2006a). Moreover, the scale of offshoring is still quite limited in the overall economy (Figure 6). Imports of intermediate manufacturing and services inputs (excluding energy) accounted for about 5 percent of gross output and about 10 percent of total intermediate inputs in advanced economies in 2003, the latest year for which data are available. These shares have increased only moderately since the early 1980s. ${ }^{6}$ The share of offshored inputs in gross

\footnotetext{
${ }^{5}$ Skilled exports are measured as exports of goods and services produced in skilled sectors, that is, sectors with a higher share of skilled workers in their labor force. The results are generally robust to excluding medium-skill sectors and focusing instead on low-skill and high-skill sectors (see Appendix I for details). Using a more refined classification of products by skill intensity, Rodrik (2006) concludes that China's export basket is much more skill intensive than would be expected given China's level of development.

${ }^{6}$ It is common to scale imported intermediates by total intermediate inputs to estimate the intensity of offshoring. However, it seems more appropriate to scale imported intermediates by total inputs (including labor and capital), since imported intermediates can substitute not only for domestic intermediate inputs but also for in-house labor and capital.
} 
output ranges from 12 percent in Canada and the Netherlands to about 2-3 percent in Japan and the United States. Offshoring is thus relatively limited in Japan and the United States, in the same way that trade openness is usually low in large economies. The manufacturing sector has been most affected by offshoring because it is more tradable. For the 10 countries for which long data series are available (G-7, Australia, Denmark, and the Netherlands), the share of imported manufacturing inputs in gross manufacturing output increased from 6 percent in 1980 to 10 percent in 2003, with the rise being somewhat stronger in the latter years of the sample (Figure 7). ${ }^{7}$ In 2003, the offshoring intensity in manufacturing ranged from 4 percent in Japan to a high of about 25 percent in Canada. Imports of service inputs by the overall economy remain low at 1 percent of gross output, although the offshoring intensity in services has increased in recent years in a number of countries including Canada, Germany, and the Netherlands. $^{8}$

Interestingly, the rise in offshoring in advanced economies has been driven mostly by imports of skilled rather than unskilled inputs. Several factors may help explain this finding. First, in line with advanced economies' comparative advantage in skill-intensive production, goods traditionally produced in unskilled sectors (e.g., textiles) are more likely to be imported as final goods rather than intermediates. ${ }^{9}$ Sectors involved in the rise of imports of intermediaries are electronic equipment; other machinery and equipment; and chemical, rubber, and plastic products. It should be noted, however, that offshoring is likely to involve the least skillintensive stages of production in these skilled sectors, although the available data do not allow confirmation of this. Second, the bulk of advanced economies' imports (of both final and intermediate products) still come from other advanced economies and likely include more skilled rather than unskilled products. Third, as mentioned earlier, the global supply of labor with higher education has increased relative to labor with lower education.

\section{How Has The Globalization OF LABor AFFECTED WORKERS IN AdVANCED ECONOMIES}

The rapid growth of the global labor supply and its manifestation through increasing exports of emerging market and developing countries naturally leads to the question of how these trends have affected workers in advanced economies. With exports from emerging market and developing countries being intensive in labor, especially unskilled labor, traditional trade theory would predict that the integration of these countries into the world economy would exert downward pressure on the wages (corrected for productivity) of workers in advanced economies. Hence, the share of national income received by labor-the so-called labor

\footnotetext{
${ }^{7}$ The flattening in 2001-02 is temporary and reflects the slowdown in world trade associated with the global recession.

${ }^{8}$ See Jensen and Kletzer (2005) and Amiti and Wei (2005) for more details on offshoring of services. The latter also find that offshoring of services remains very limited, although it has grown in recent years.

${ }^{9}$ The share of imported intermediates in total imports of unskilled products is lower than the comparable share for skilled products, at 37 percent and 68 percent, respectively.
} 
share-would be expected to decline. To see this, it is worth noting that the labor share can be expressed as the ratio of labor compensation per worker to average worker productivity.

Nevertheless, workers in advanced economies could still be better off if the positive effects from enhanced trade and productivity on the economy's income (the size of the total "pie") are larger than the negative effects on the share of this income that accrues to labor. The vast literature documenting gains from trade (see, for example, Lewer and Van den Berg, 2003; Berg and Krueger, 2003) suggests that the increase in the economy's income may indeed be substantial. Recently, Grossman and Rossi-Hansberg (2006) have argued that the productivity-enhancing effect from trade in intermediates could be even larger than for trade in final goods because, in addition to a competition effect for producing sectors, it also reduces the costs of production of using sectors. The empirical evidence on the productivity effects of offshoring is, however, mixed. ${ }^{10}$

What do the data show? Looking first at the labor share, there has been a clear decline since the early 1980s across the advanced economies (Figure 8). ${ }^{11}$ The decline is stronger for the labor share than for the share of employees' compensation, reflecting a reduction in the share of other categories of workers in the total workforce (other categories of workers include self-employed, employers, and family workers). ${ }^{12} \mathrm{~A}$ part of this decline is a reversal of the rise in labor shares that took place in the 1970s, especially in Europe and Japan (Blanchard, 1998). ${ }^{13}$

\footnotetext{
${ }^{10}$ There is little empirical evidence on the productivity effects of offshoring to date (see Olsen, 2006). There are some indications that positive productivity effects of manufacturing offshoring depend on the degree to which firms are already globally engaged. However, their global engagement may be already close to optimal levels in advanced economies, suggesting that the potential for productivity gains from services offshoring may be larger. Positive productivity effects of services offshoring to date appear to be generally small in manufacturing plants, but somewhat bigger in service-sector firms. Amiti and Wei (2006) find a significant positive effect of services offshoring and a somewhat smaller positive effect of manufacturing offshoring on productivity in the United States.

${ }^{11}$ National accounts provide the share of employees' compensation in total income but do not identify separately the labor income of other categories of workers (self-employed, employers, and family workers). Several correction procedures are available (Gollin, 2002) and, for data availability reasons, the employees' compensation was augmented with compensation of other categories of workers by assuming that the latter command similar wages per worker as employees. The results are robust if other procedures are used (see Appendix I).

${ }^{12}$ Focusing on the United States for which data are available since 1930, the share of employees' compensation in national income does not appear to be at a historical low (though this may be partly related to the rise in the share of employees in the total workforce).

${ }^{13}$ Blanchard (1998) argues that the rise of the labor share in Europe in the 1970s was driven by a negative shift in labor supply as wages did not adjust fast enough to the slowdown in underlying factor productivity growth. Over time, though, employment adjusted downward, exerting downward pressure on wages and returning the labor share toward its previous level (though at a higher unemployment rate). The further decline that has taken place in the labor share since the mid-1980s is the result of an adverse labor demand shock: at a given wage and capital stock, firms have steadily decreased employment. Such a shift may have various sources: the adoption of technologies biased against labor and toward capital or a shift in the distribution of rents away from workers.
} 
The decline in the labor share since 1980 has been much more pronounced in Europe and Japan (about 10 percentage points) than in Anglo-Saxon countries, including the United States (about 3-4 percentage points). ${ }^{14}$ Within Europe, the strongest decline is observed in Austria, Ireland, and the Netherlands. Further, most of the decline in the labor share can be attributed to the fall in unskilled sectors, which was more pronounced in Europe and Japan than in the Anglo-Saxon countries. This decline reflects a combination of the reduction in the withinsector labor share and the shift of output from unskilled toward skilled sectors (see Figure 8). The income share of labor in skilled sectors, on the other hand, has been on the rise, especially in Anglo-Saxon countries where it has increased by about 5 percentage points. It is important to emphasize that, due to the nature of the available data, these results relate to income shares of workers in skilled and unskilled sectors, rather than the income shares of skilled and unskilled workers themselves.

Despite the fall in the overall labor share, real labor compensation has expanded robustly in all advanced economies since 1980 with growth accelerating since the mid-1990s. This trend reflects both employment growth and increases in real compensation per worker, with a stronger weight on employment in the Anglo-Saxon countries and on real compensation per worker in Europe (Figure 9). Since the mid-1990s, however, employment growth has picked up in Europe, outpacing the growth in real compensation per worker. Growth in labor compensation of unskilled sectors, however, has been very sluggish (Figure 10). While unskilled employment has held steady in the United States, increases in real compensation per worker have been meager in unskilled sectors and the earnings gap between skilled and unskilled sectors has widened by 25 percent. In Europe, real compensation per worker in unskilled sectors grew broadly in line with that in skilled sectors, but employment in unskilled sectors lost ground to employment in skilled sectors (and actually contracted by a cumulative 10 percent). ${ }^{15}$

Turning to emerging market countries, theory would predict that the globalization of labor would bring large benefits for workers in the form of wage convergence toward the levels in advanced economies. Data from the manufacturing sector confirm that real wages in emerging market countries, particularly in Asia, have been catching up with those in the United States (Figure 11). Real wages (corrected for purchasing power) have been converging rapidly and are relatively high in Asian countries that started developing earlier (Hong Kong SAR, Korea, Singapore, and Taiwan Province of China). Wages in other Asian countries, including China, have been converging at a slower pace, though this has accelerated in recent years. ${ }^{16}$ Studies confirm that both trade and emigration have contributed to rising incomes of nationals of developing countries, although the evidence on their impact on inequality is mixed (see

\footnotetext{
${ }^{14}$ For the purpose of this paper, Europe includes the euro area countries, Denmark, and Norway, while AngloSaxon countries include Australia, Canada, the United Kingdom, and the United States.

${ }^{15}$ Katz and Autor (1999) find similar changes in the gap between high- and low-income earners for the United States and European countries.

${ }^{16}$ Asia’s labor productivity has also been converging toward the U.S. level (see International Monetary Fund, 2006).
} 
International Monetary Fund, 2007, Box 5.1 for a discussion of the evidence on the implications of globalization for labor markets in developing countries).

\section{LABOR SHARE AND THE GLOBALIZATION OF LABOR: AN EMPIRICAL EXAMINATION}

\section{A. Explaining the Labor Share}

While striking, the globalization of labor is but one of the forces that has been affecting the labor markets of advanced economies over the last two decades. Rapid technological change is another central development with potentially important implications for labor market outcomes (Figure 12). The information and communications technology (ICT) revolution, an all-purpose technological revolution, which Blinder (2006) has compared to the third industrial revolution, has stimulated capital accumulation (see the September 2001 World Economic Outlook) and favored skilled labor-with which it is more complementary-over unskilled labor. Technology has also progressed in other areas as reflected in the strong rise in patent applications in OECD economies, especially since the early 1990s.

The literature linking labor market conditions to globalization and technological progress is quite extensive. Most studies have focused on explaining the decline in the relative wage (or labor share) of unskilled workers in the United States (see Freeman, 1995 and Feenstra, 2004 for a survey). Studies that attempt to explain the evolution of the overall labor share are more scarce. Most studies conclude that skill-biased technological change is a more important cause of wage inequality than trade (e.g., Harrigan, 1998; and Harrigan and Balaban, 1999). Feenstra $(2004,2007)$ finds that the role of trade and technological progress are equally important in explaining rising wage inequality. In a recent contribution, Guscina (2006) finds that labor shares across countries are equally affected by technological progress and openness. Harrison (2002) also finds that globalization tends to reduce the labor share. Another strand of the literature examines whether globalization increases the elasticity of labor demand to wages and finds mixed results (see, for instance, Slaughter, 2001 and OECD, 2006a). Studies of immigration tend to find that its effects on wages and employment of natives are small (Greenwood, Hunt, and Kohli, 1996; OECD, 2006b).

Changes in labor and product market policies constitute another force affecting labor across advanced economies. Reforms have proceeded in several areas, but generally in the direction of lowering the cost of labor to business and enhancing the flexibility of markets. Four main developments in labor market policies are particularly worth noting (see Figure 12): (1) a marked increase in the generosity of unemployment benefits in Europe (as measured by average replacement rate of income), in contrast with a slight decline in Anglo-Saxon countries; (2) a general decline in the tax wedge, especially in the United States where it has fallen by about 10 percentage points since 1995; (3) substantial declines in legislated employment protection and product market regulation, especially in Europe and Japan, both of which started with particularly restrictive stances; and (4) persisting large cross-country differences in the degree of employment protection, with low protection in the United States and other Anglo-Saxon countries and relatively high protection in Europe and Japan. Recent studies (Bassanini and Duval, 2006; Annett, 2006) have highlighted reductions in the tax wedge, reductions in unemployment benefits, deregulation of product markets, and more 
limited employment protection as the main factors that have contributed to employment growth and declining unemployment. ${ }^{17}$ Disentangling the influence of these variables is difficult, in particular because technological change and the globalization of labor may be expected to affect compensation and the labor share in similar ways. The influence of policy variables is complex, particularly because they may also affect the labor share indirectly by facilitating or obstructing the adjustment of the economy to labor globalization and technological progress.

\section{B. Empirical Methodology}

This section uses an econometric model to analyze the relationship between the labor share and labor globalization - measured in terms of trade prices, offshoring, and immigrationcontrolling for technological progress and changes in labor market policies. The basic model, which has solid microeconomic foundations, is widely used in the recent trade literature (see, for instance, Feenstra, 2004; Harrigan, 1998; and Kohli, 1991). It gives rise to a labor share equation with export and import prices (relative to that of domestic absorption) and the laborcapital ratio on the right hand side (Appendix II explains how this equation is derived). The export and import prices capture the effects of trade globalization: declines in import prices are expected to decrease the labor share, as imports that come increasingly from developing countries are labor intensive; in contrast, declines in export prices should benefit labor relative to capital because of the high capital intensity of advanced economies' exports. The basic model is augmented with the intensity of offshoring, the share of immigrants in the domestic labor force, the share of ICT capital in total capital, and measures of labor market policies (specifically, the tax wedge, the replacement rate of unemployment benefits, indices of product market regulation, employment protection legislation, and union density), all introduced as shifters of the revenue function as suggested by Feenstra (2004). The effect of ICT capital is represented by a quadratic function to reflect potential nonlinearities associated with the need for learning the new technology: the adverse effect on wages and employment is likely to be greatest before workers acquire the skills necessary to effectively handle the new equipment. Thus, the following equation was adopted as the specification for the analysis:

$$
R_{L}=\beta_{L}+\gamma_{E L} \ln \frac{p_{E}}{p_{A}}+\gamma_{M L} \ln \frac{p_{M}}{p_{A}}+\beta_{L L} \ln \frac{L}{K}+\phi_{L X} X+\phi_{L M} \frac{L_{M}}{L}+\phi_{L C} \frac{K_{I C T}}{K}+\phi_{L C 2}\left(\frac{K_{I C T}}{K}\right)^{2}+\phi_{L P} L M P+\varepsilon_{L},
$$

where $P_{E}, P_{M}$, and $P_{A}$ are prices of exports, imports, and absorption, $L$ is labor; $K$ is capital; $X$ is the intensity of offshoring; $L_{M}$ is immigrant employment; $K_{I C T}$ is ICT capital, and $L M P$ are labor market policies. At the outset, it should be noted that the effects of globalization can

\footnotetext{
${ }^{17}$ Some of these variables may also affect the labor share in similar ways, especially if the elasticity of substitution between labor and capital is high. For instance, an increase in the unemployment benefit replacement rate increases the reservation wage of workers and leads in the very short run to a rise in the labor share. But as employment adjusts downward, the labor share declines and can fall below its initial level if the elasticity of substitution between capital and labor is high enough (Blanchard, 1998). Other shocks that increase the cost of labor, such as an increase in the tax wedge or an increase in employment protection, can be expected to have similar effects. Although strict product market regulation creates rents, it is not clear that it should affect the distribution of these rents between labor and capital and hence the labor share.
} 
only be imperfectly disentangled from those of technology, especially for technological progress in transport and communication, which vastly expands the opportunities for globalized production. Similarly, part of the decline in import (and, in some cases, export) prices may be attributable to productivity improvements in the production of information and communications technology.

The model was estimated on an unbalanced panel of 18 advanced OECD economies over 1982-2002. Labor shares were corrected for the income of self-employed; prices and the capital stock variables were measured in 2000 U.S. dollars; and labor stock variables were represented by employment. Offshoring is measured as a share of imported intermediate inputs in total intermediate inputs, immigration is captured as a share of immigrant employment in total domestic employment, and ICT capital is modeled as a share of ICT capital in the total capital stock (more detail on these measurements is provided in Appendix I). The left- and right-hand side variables are demeaned using country-specific means (equivalent to doing a panel estimation with country fixed effects) and time dummies are included in the equations to capture common shocks across countries. A potential concern with the accuracy of the estimation is that the variables related to labor globalization-trade prices, offshoring, and immigration - may be endogenous. Trade prices are unlikely to be exogenous for countries whose economic size is sufficiently large.$^{18}$ Reverse causality or common third factors may bias the effects of offshoring and immigration on the labor share. To address this concern, an instrumental variables estimation was used with variables reflecting domestic and foreign supply and demand conditions, as well as lags of the potentially endogenous variables as instruments. Specifically, the list of instruments included the share of government consumption in GDP; the consumption tax rate; the (log of) total population; the (log of) export-weighted real GDP of trading partners; the distance-weighted export-adjusted employment in the rest of the world; ${ }^{19} 0$ and lags of (logs of) relative trade prices, offshoring, and immigration.

In addition to the aggregate labor share equation, a system of labor share equations for workers in skilled and unskilled sectors was also estimated as follows:

\footnotetext{
${ }^{18}$ Also, the price of absorption could be affected by changes in the labor share, which reflect changes in unit labor costs.

${ }^{19}$ In this way, the global labor supply discussed in Section II enters as a determinant of trade prices, offshoring, and immigration-the channels through which it may affect the labor share.
} 


$$
\begin{aligned}
& R_{S}=\beta_{S}+\sum_{k=E, M} \gamma_{k S} \ln \frac{p_{k}}{p_{A}}+\sum_{k=S, U} \beta_{S k} \ln \frac{L_{k}}{K}+\phi_{S X} X+\phi_{S M} \frac{L_{M}}{L}+\phi_{S C} \frac{K_{I C T}}{K}+\phi_{S C 2}\left(\frac{K_{I C T}}{K}\right)^{2}+\phi_{S P} L M P+\varepsilon_{S} \\
& R_{U}=\beta_{U}+\sum_{k=E, M} \gamma_{k U} \ln \frac{p_{k}}{p_{A}}+\sum_{k=S, U} \beta_{U k} \ln \frac{L_{k}}{K}+\phi_{U X} X+\phi_{U M} \frac{L_{M}}{L}+\phi_{U C} \frac{K_{I C T}}{K}+\phi_{U C 2}\left(\frac{K_{I C T}}{K}\right)^{2}+\phi_{U P} L M P+\varepsilon_{U},
\end{aligned}
$$

where $S$ and $U$ denote skilled and unskilled sectors, respectively, and the other variables are the same as above (see Appendix II). The labor share of workers in skilled (unskilled) sectors refers here to the ratio of labor compensation in skilled (unskilled) sectors to economy-wide value added. A symmetry restriction postulates that the coefficients on the (log of) laborcapital ratio of the unskilled sectors in the first equation and of the skilled sectors in the second equation are the same. Again, left- and right-hand side variables were demeaned using country-specific means (equivalent to doing a panel estimation with country fixed effects) and time dummies were included in the equations. The system was estimated imposing the symmetry restriction, first by iterated seemingly unrelated regressions and then by iterated three-stage least squares using the instruments listed above.

\section{Estimation Results}

The estimation results from the aggregate labor share equation are shown in Table 1. Most of the variables are statistically significant and have expected signs:

- $\quad$ Higher relative export prices and lower relative import prices are associated with a lower labor share. This is consistent with advanced economies' exports being relatively capital intensive and their imports that increasingly come from developing countries being relatively labor-intensive.

- $\quad$ Offshoring and immigration are negatively related to the labor share, consistent with the rising global labor supply exerting a negative effect on domestic labor demand. The coefficients on these variables in the instrumental variables regression are somewhat larger in absolute value, suggesting the presence of reverse causality: a lower labor share, which reflects lower unit labor costs, makes offshoring less appealing for domestic firms and makes immigration less attractive for foreign workers.

- $\quad$ Technological progress appears to have a nonlinear effect on the labor share, consistent with the idea that labor-saving innovations initially create the need for extra learning on the part of workers, but enhance their productivity later on as the necessary skills are acquired.

- $\quad$ Among the policy variables, only higher tax wedges and unemployment benefit replacement rates are associated with a lower labor share, reflecting labor market rigidities stemming from these policies. The negative effect of the tax wedge and the unemployment benefit replacement rates on the labor share suggests that they reduce employment more than they increase labor costs. Other labor and product market variables, specifically, the index of employment protection legislation, the index of product market regulation, and the union density measure, were not statistically significant and were, therefore, excluded from the preferred specification. The capital- 
labor ratio is also generally insignificant once labor market policies are included in the regressions..$^{20}$

The findings are generally robust to the exclusion of outliers (identified in terms of their influence on predicted values and the variance-covariance matrix of the estimates) and of individual countries. Partial correlation plots, showing the correlation between the labor share and each regressor after controlling for the other explanatory variables, confirm that the estimated relationships are quite robust (Figure 13). Table 2 presents a number of alternative specifications which further test the robustness of the results. In column 1, using ICT investment instead of ICT capital retains the non-linear effect of technological progress, while the other coefficients are unaffected. Column 2 splits the import price into those of oil and non-oil imports, confirming that the estimated coefficient on the import price is not driven by the behavior of oil prices, whose effect on the labor share is insignificant. Column 3 distinguishes between offshoring of unskilled and skilled inputs: in line with the evidence presented earlier that most of the increase in offshoring was in skilled inputs, only the latter has a significant negative effect on the labor share. Finally, column 4 tests the robustness of the results to the inclusion of a variable measuring financial openness. Financial globalization is another force which may have reduced the labor share, as the greater ease with which capital can cross borders may have reduced the bargaining power of workers, the relatively less mobile factor of production. ${ }^{21}$ Financial openness is measured as the sum of cross-border assets and liabilities in GDP and instrumented by the distance-weighted financial openness in the rest of the world (see Tytell and Wei, 2004 for a discussion of this instrument). While the coefficient on this variable is negative, it is not statistically significant and other coefficients are broadly unaffected. ${ }^{22}$

The estimation results from the labor share equations for skilled and unskilled sectors are shown in Table 3. Labor globalization and technological progress appear to have somewhat different effects on the labor shares of workers in skilled and unskilled sectors. Labor globalization has a somewhat stronger effect on the skilled sectors, in line with the evidence presented earlier that the increase in offshoring occurred mostly in the skilled sectors and that recent immigrants have relatively high education levels ${ }^{23}$. Technological change affects both skill groups negatively, but the effect is less strong for the skilled, consistent with the

\footnotetext{
${ }^{20}$ Instrumenting for the capital-labor ratio using its lagged value or dropping the share of immigrants in the domestic labor force did not make the coefficient significant.

${ }^{21}$ The effect of financial globalization on the domestic capital stock is captured indirectly through the laborcapital ratio. However, this variable turned out to be insignificant for the labor share, once labor market policies are controlled for.

${ }^{22}$ Interestingly, the coefficient on financial openness is statistically significant in the non-instrumented version of the regression. This finding could reflect reverse causality that is eliminated by instrumenting. One source of reverse causality could be as follows: as the share of capital increases, more proceeds are invested abroad, raising the amount of foreign assets and therefore the measure of financial openness.

${ }^{23}$ As discussed above in Section II, the available data allow a distinction between skilled and unskilled sectors, rather than skilled and unskilled workers. This should be kept in mind when interpreting the econometric results.
} 
nonlinearity due to learning requirements, as suggested above. Finally, although product market regulation has a negligible impact on the overall labor share, it seems to benefit labor in unskilled sectors. These results should be treated as somewhat more tentative, however, given that the classification by skill is based on broad economic sectors. ${ }^{24}$

\section{THE STORY BEHIND THE DECLINE OF THE LABOR SHARE}

The decline in the labor share observed over 1982-2002 can be decomposed into the contributions of globalization, technological progress, and changes in labor market policies. The contributions of the various factors are calculated as the average annual change in the respective variable multiplied by the corresponding coefficient estimate in the IV estimation of the preferred model (see column 4 of Table 1 ). ${ }^{25}$ These contributions allow introducing cross-country differences in the role of various factors, although they do not fully reflect cross-country heterogeneity, since the estimated coefficients are the same for all countries in the sample.

The results from this decomposition suggest that labor globalization, technological change, and labor market policies have all affected labor shares over the past two decades (Figure 14). Both labor globalization and technological progress have acted to reduce the labor share, with the impact of technological progress being generally somewhat larger, while changes in labor market policies have generally had a smaller but positive impact on the labor share. Each channel of labor globalization (trade prices, offshoring, and immigration) individually plays a relatively small role in explaining the decline in the labor share.

Labor globalization contributed to the decline in labor shares in most countries, with broadly similar effects in both Anglo-Saxon countries and Europe. ${ }^{26}$ Nevertheless, the labor globalization effect in the Anglo-Saxon countries and Europe is driven by different factors. Europe's labor share has been affected both by offshoring and immigration, while, in the Anglo-Saxon countries, offshoring was a somewhat less important factor. Similarly, within Europe, large economies were affected more by immigration than offshoring, while the opposite holds for small economies. The third component of globalization-the change in trade prices - generally had only a small net effect on the labor share. Hence, while globalization exerted downward pressure on the labor share through declines in import prices, this effect has been broadly compensated by similar declines in export prices, which have

\footnotetext{
${ }^{24}$ The results were robust to including the measure of financial openness, which had an insignificant effect for the labor shares of workers in both skilled and unskilled sectors.

${ }^{25}$ The averages across country groups are weighted by the number of years of data available for each country, so that countries with more data receive a larger weight in these averages.

${ }^{26}$ Some caution is needed when interpreting these results, since they are based on the regression coefficients that are the same for all the countries and average annual changes in variables that are country specific. Further, sample years differ somewhat across countries, which should be kept in mind when doing cross-region comparisons.
} 
boosted the labor share since exports of advanced economies are capital intensive. In large European countries and Japan, the net effect from changes in trade prices was actually to boost the labor share.

The reasons for the milder decline of the labor share in the Anglo-Saxon countries than in Europe are found in the role of technological change and labor market policies rather than in the differences in the impact of labor globalization. ${ }^{27}$ Technological change has contributed to the reduction of the labor share in both groups, but less so in the Anglo-Saxon countries. In particular, in the United States, ICT capital even contributed to raise the labor share, possibly reflecting the fact that the United States is most advanced in the use of IT. The adverse labor demand effects of ICT appear to be stronger at the early stages of ICT adoption before the needed adjustments in workers' education have taken place. Changes in labor market policies have had a positive effect on the labor share in Anglo-Saxon countries, but a much more modest effect on average in Europe, particularly in large European economies where labor policies are estimated to have actually contributed to a decline in the labor share. The contribution of labor market policies is driven primarily by the changes in the tax wedge and unemployment benefit replacement. The decline in the tax wedge in Anglo-Saxon countries, especially in the United States, benefited the labor share, while in Europe the labor share was hurt by a rise in unemployment benefit replacement rates.

Turning to look at the skilled and unskilled sectors separately, the main factor affecting the income share of labor in unskilled sectors over the sample period, beyond the shift of employment toward skilled sectors, is technological change (Figure 15). This result is consistent with the belief that computers and other ICT equipment act as a substitute for unskilled labor, but they tend to complement skilled labor. On the other hand, labor globalization contributed to a decline in the income share of labor in skilled sectors, much more so than in unskilled sectors. This is in line with earlier findings that the increase in offshoring was mostly driven by the offshoring of skilled inputs rather than unskilled inputs, and similarly that a majority of the new immigrants had tertiary or at least secondary education. However, this was more than offset by the shift of employment from unskilled sectors to skilled sectors and the income share of labor in skilled sectors actually increased moderately. ${ }^{28}$

\footnotetext{
${ }^{27}$ These two factors explain about half of the difference between the changes in the labor shares of Anglo-Saxon countries and Europe. The other half is accounted for by different contributions of time dummies (due to the difference in sample periods) and by the residual.

${ }^{28}$ Workers in unskilled sectors have also benefited somewhat less from labor market policy changes. Although product market regulation has a negligible impact on the overall labor share, it seems to benefit labor in unskilled sectors. Hence, the reduction in product market regulation over the sample period had a negative effect on the income share in unskilled sectors.
} 


\section{LABOR COMPENSATION PER WORKER, EMPLOYMENT, AND LABOR GLOBALIZATION: WHAT CAN WE SAY?}

Of course, the effects on labor shares do not by themselves give the full picture of how workers' well-being is affected by forces of globalization and technological change. These factors also influence output and hence total labor compensation. The econometric model used in this paper allows going beyond the effects of various factors on the labor share by computing the elasticities of labor compensation per worker and employment to trade prices (see Appendix II and Kohli, 1991). The (short-run) elasticities of labor compensation per worker to trade prices (given employment) are obtained as follows:

$$
\varepsilon\left(W, p_{i}\right)=\frac{\gamma_{i L}}{R_{L}}+S_{i},
$$

where $i=E$ (exports), $M$ (imports) and the output shares $R_{L}$ and $S_{i}$ are evaluated at the mean for each country.

The (long-run) employment elasticities with respect to trade prices (given labor compensation per worker) are obtained as follows:

$$
\begin{gathered}
\varepsilon\left(L, p_{i}\right)=-\frac{\varepsilon\left(W, p_{i}\right)}{\varepsilon(W, L)}, \\
\text { where } \varepsilon(W, L)=\frac{\beta_{L L}}{R_{L}}+R_{L}-1 \text { and } i=E \text { (exports), } M \text { (imports). }
\end{gathered}
$$

It is important to point out that these elasticities are derived from the model that assumes fixed prices, hence possible price adjustments are not taken into account in these calculations. To compute the actual percent changes in labor compensation per worker and employment resulting from changes in trade prices, these elasticities are multiplied by the average percent changes in relative trade prices in each country. ${ }^{29}$ The results are shown in Figure 16.

On average, a 1 percent decline in the relative price of imports in advanced countries raises labor compensation per worker by 0.1 percent (for given employment) and employment by 0.3 percent (for given labor compensation per worker). In contrast, a 1 percent decline in the relative price of exports lowers labor compensation per worker by about 0.05 percent (for given employment) and employment by 0.2 percent (for given labor compensation per worker). Combining these elasticities with the actual changes in relative export and import prices over the period 1980-2004 for advanced countries implies a net cumulative increase of 2 percent in labor compensation per worker for given employment (or 0.08 percent on an annualized basis) and of 6 percent in employment for given labor compensation per worker

\footnotetext{
${ }^{29}$ The averages across country groups are weighted by the number of years of data available for each country, so that countries with more data receive a larger weight in these averages.
} 
(or 0.24 percent on an annualized basis). These effects are slightly larger for Anglo-Saxon countries and Japan.

The implied output effect of changes in trade prices can easily be calculated using the definition of the labor share:

$$
Y=\frac{w L}{R_{L}}
$$

Under the assumption of fixed employment, the implied output effect is close to zero (and even negative in some countries) and the 2 percent increase in labor compensation per worker reflects mostly the increase in the labor share brought about by the decline in traded goods prices. However, when labor compensation per worker is held fixed, the decline in traded goods prices also generates a positive output effect of the order of 4 percent, bringing the total employment gain to 6 percent.

The model results thus imply that the decline in traded goods prices in advanced countries yielded a small but positive increase in labor compensation per worker (in real terms) and employment over 25 years. Thus, although the labor share went down, globalization of labor as manifested in cheaper imports in advanced economies has increased the "size of the pie" to be shared among all citizens, resulting in a net gain in total workers" compensation in real terms. ${ }^{30}$

In sum, the econometric analysis suggests that both labor globalization and technological change have been important factors behind the observed decline in labor shares in advanced economies. The rapid progress in ICT has had a particularly strong effect on the unskilled sectors. The role of labor market policies has differed across countries, with positive effects largest in the United States and much more modest on average in Europe (and negative in some countries). Finally, global competition has brought down international trade prices. Cheaper imports have increased the size of real total labor compensation, implying that workers have participated in the benefits of the bigger economic "pie," although their share of it has declined.

\section{SUMMARY AND POLICY IMPLICATIONS}

There has been a dramatic increase in the size of the effective global labor force over the past two decades, with one measure suggesting it has risen fourfold. This expansion is expected to continue in the coming years. The UN projects a 40 percent rise in the world's working-age population by 2050, and trade openness will continue to grow, especially in services. Indeed,

\footnotetext{
${ }^{30}$ It should also be noted that a comprehensive evaluation of the impact of globalization on workers' financial means needs to go beyond labor compensation and to take into account an increase in direct and indirect asset ownership (see International Monetary Fund, 2006).
} 
tentative projections suggest that the effective global labor supply could more than double again by $2050 .^{31}$

The global pool of labor can be accessed by advanced economies through imports and immigration. Trade is the more important and faster-expanding channel, in large part because immigration remains very restricted in many countries. But the integration of China, India, and the former Eastern bloc countries into the world economy has also expanded export markets for advanced economies. Contrary to popular perceptions, the intensity of offshoring of the production of intermediates is still small in the overall economy, although the manufacturing sector is more affected owing to its greater tradability. Imports of offshored intermediates have also been growing somewhat more slowly than total trade.

The integration of workers from emerging market and developing countries into the global workforce has produced important benefits for advanced economies. It has provided access to cheaper imported goods and has enabled companies to operate more efficiently. This has boosted productivity and output, and contributed to rising real labor compensation. For emerging market economies, the ongoing integration of labor into the global marketplace has benefited workers, with manufacturing wages rising rapidly.

Nevertheless, labor globalization has negatively affected the share of income accruing to labor in the advanced economies (the labor share). It is, however, only one of several factors that have affected the labor share over the past two decades. Rapid technological changeespecially in the information and communications sectors-has had a bigger impact, particularly on the labor share in unskilled sectors.

Against this background, the increasing globalization of labor raises important challenges for policymakers in the advanced economies. They must seek to harness the benefits that the growing pool of global labor is creating. This means continuing along the path of trade liberalization, while ensuring that domestic economies are sufficiently flexible to be able to adjust and respond to the pressures of globalization. At the same time, it is important to be fully cognizant of adjustment costs, and policies do need to support those people negatively affected by labor market globalization. In broad terms, policies need to respond along three dimensions:

- $\quad$ Improve the functioning of labor markets. Steps to reduce tax wedges to enable workers to take home a larger proportion of their gross pay and to ensure that unemployment benefit replacement rates do not deter workers from seeking employment have helped a number of countries adjust to the pressures of

\footnotetext{
${ }^{31}$ This projection is based on the medium-variant of the UN projections of working-age population and on the assumption that the ratio of non-oil exports to GDP will continue expanding at the rate observed in recent years (see Appendix I). World Bank (2006) also provides projections of the world's workforce until 2030 and projects that although the vast majority of the world's workforce will remain unskilled, the supply of skilled workers is likely to grow faster than that of unskilled workers.
} 
globalization. The duration of unemployment benefits and the work availability requirements are also important (see Annett, 2006; and Bassanini and Duval, 2006). Moreover, policies that increase the flexibility of the economy and thereby enable workers to move more easily from declining to expanding areas of the economy help the process of adjustment. A variety of country-specific approaches are possible, as demonstrated by the range of experience of successful reformers in western Europe (see International Monetary Fund, 2007, Box 2.2 for a discussion of these experiences). Reform packages also have to be designed with fiscal consequences in mind.

- Improve access to education and training. Developing workers' skills is necessary for keeping up with rapid technological change and for continuing innovation. Skilled sectors have been better able to adapt to changing conditions caused by the ICT revolution than unskilled sectors. Further, countries that started adopting ICT and training workers in this area earlier experienced less decline in their labor share. Workers must also be ready to compete with the growing pool of skilled workers in emerging markets, especially those in Asia. Beyond increases in spending on education and training, the quality of this spending is crucial. Experience shows that evaluation and targeting of training are important to maximize its impact.

- $\quad$ Ensure adequate social protection for workers during the adjustment period. This includes providing adequate income support to cushion, but not obstruct, the process of change, and also making health care less dependent on continued employment and increasing the portability of pension benefits in some countries, which would also enhance the flexibility of the economy by facilitating the move of workers from declining sectors to expanding sectors. Whether measures specifically targeted at workers who have been displaced by international trade are desirable is less clear (see, e.g., OECD, 2005). The fact that these workers may face special hurdles reintegrating into the labor market as they are often older and less educated and their skills are specific to declining industries or occupations argues in favor of such measures. Also, minimizing losses for such workers may increase support for the international economic integration process. However, it may be difficult (even conceptually) to differentiate between job losses caused by globalization and those caused by other factors, since most labor markets are characterized by high rates of turnover and yearto-year earnings variability anyway. If trade-displaced workers are treated more generously, including, for instance, by being provided supplementary wage subsidies, such compensation should be structured to avoid dulling incentives to search actively for new jobs. 


\section{APPENDiX I. DAta SourCeS AND MethodS}

This appendix provides further details on the construction of the variables used in the paper and the sources of the data.

\section{Sectoral Classification}

Throughout the paper, the analysis is carried out both for the aggregate economy and for a disaggregation of the economy by skill category. The classification of trade and labor into skill categories is based on the skill intensity of the sector. Hence skilled exports are exports of goods and services typically produced by skill-intensive sectors. The skilled labor share is the share of national income that accrues to workers in skill-intensive sectors. One drawback of this approach is that it does not capture changes that occur between skilled and unskilled workers within sectors. A more refined approach was, however, not feasible because of the lack of cross-country data on the wages of production (unskilled) and nonproduction (skilled) workers, which would have been needed to calculate labor shares and labor compensation of skilled and unskilled workers.

The classification of sectors into skilled and unskilled is based on the share of skilled workers in the labor force of the sector, where a person is considered skilled if he or she has at least upper secondary education. Data on the average fraction of skilled labor in each sector (across 16 OECD economies from 1994 to 1998) are from Jean and Nicoletti (2002). The paper classifies 18 sectors (from the International Standard Industrial Classification, Revision 3) into two broad aggregates, namely, unskilled and skilled sectors, as reported in Table 4. In order to test the robustness of the stylized facts, an alternative three-category split was also used, which distinguishes between low-skill, medium-skill, and high-skill sectors. Figure 17 shows that the patterns of the labor shares (and relative labor compensation per worker) for the narrower high- and low-skill aggregates are similar to those for the broader skilled and unskilled aggregates.

\section{Labor Compensation and Labor Shares}

Labor compensation was calculated by augmenting the compensation of employees for the income of other categories of workers (self-employed, employers, and family workers). Following Gollin (2002) and for data availability reasons, it was assumed that other categories of workers earn the same average wage as employees. Labor compensation is hence the product of the compensation of employees and the ratio of total employment and employees. ${ }^{32}$ Other correction procedures (see Gollin, 2002, for a review), for which the data are not widely available, yield similar patterns over the subset of the sample used in this paper for which the data are available. This correction was applied at both the aggregate and the sectoral level of data. When sectoral data on employees or total employment were not available, the following procedure was used:

\footnotetext{
${ }^{32}$ Korea was excluded from the sample because some of the income of the self-employed is already in the employees' compensation, making it impossible to apply the correction (see also Young 1995 and 2003).
} 
- $\quad$ the ratio of total employment to total employees was assumed to be the same as in previous years or, if it was not available for any year, it was assumed to be equal to the average for this sector across other OECD economies; and

- $\quad$ the sum of "nonemployee" workers across sectors was constrained to add up to the total for the aggregate economy by scaling the imputed number of nonemployee workers proportionately.

The variables are defined as follows. Real labor compensation is labor compensation deflated by the CPI index from the IMF's World Economic Outlook database. The labor share is calculated as the ratio of labor compensation and value added at basic prices. ${ }^{33}$ The share of labor in skilled (unskilled) sectors is the ratio of labor compensation in skilled (unskilled) sectors to the economy-wide value added.

The main data source is the OECD’s Structural Analysis (STAN) database. However, several other sources were used to fill in missing data and extend the series to the most recent year possible. For employees' compensation and value added, these include the OECD National Accounts Statistics, the United Nations National Accounts Statistics, and Haver Analytics (for Japan). For data on total employment and employees, the additional sources were the OECD Employment and Labor Market Statistics and the ILO Labor Statistics databases. Due to data availability reasons, the calculations were limited to advanced OECD economies.

\section{Manufacturing Wages}

Manufacturing wages for advanced and developing economies are from the UNIDO Industrial Statistics Database. They were converted into constant purchasing power parity (PPP) dollars using CPI indices and PPP exchange rates from the IMF's World Economic Outlook database. The data for China are from the CEIC Asia database.

\section{Immigration}

The data on foreign labor force are from the OECD's Trends in International Migration (2003 edition for all countries except the United States). For the United States, the data are from the U.S. Bureau of Census and the U.S. Bureau of Labor Statistics. Data for Italy, the Netherlands, Norway, and the United Kingdom are for foreign employment instead of labor force. Data for Australia, Canada, and the United States refer to foreign-born labor force instead of foreign labor force. The available series were extended backward using growth rates from the stock of foreign (or foreign-born, in the case of Australia, Canada, and the United States) population when available, and the missing years were interpolated.

\footnotetext{
${ }^{33}$ The exceptions are Japan, where value added is measured at producer prices, and the United States, where it is measured at market prices.
} 
Data on emigration and immigration by skill level for 1990 and 2000 are from Docquier and Marfouk (2005) and refer to the stock of emigrants to or immigrants into the OECD economies.

\section{Trade and Offshoring}

Data on trade used in the paper are from a variety of sources. Aggregate data on trade quantities and prices are from the IMF's World Economic Outlook database, including for the non-oil goods and services aggregates. Sectoral trade data for advanced economies (used to construct skilled and unskilled trade) are from the OECD STAN Industrial Database (for manufacturing) and from the OECD International Trade in Services Database (for services). For developing countries, sectoral trade data were obtained from the World Integrated Trade Solution (for manufacturing) and from the IMF's Balance of Payments Statistics (for services). Data on manufacturing trade of advanced OECD economies by source country are from OECD STAN Bilateral Trade Database. The services data for India were extended using the CEIC Asia database.

Offshore outsourcing is the outsourcing of intermediate production to companies in locations outside the country, which can be foreign affiliates or independent companies. It is measured by the imports of intermediate inputs, as provided in the OECD Input-Output Tables (1995, 2002, and 2006 editions). These tables assume that an industry uses an import of a particular product in proportion to its total use of that product ("the import proportionality assumption"), and this proportion is the economy-wide share of imports in domestic demand. The measure used in the paper only includes nonfuel manufacturing and services inputs. Imported intermediate inputs of a sector are scaled by either the sector's gross output or its total use of intermediates. Sectoral offshoring intensities are then aggregated based on sectoral gross output weights. Finally, the data on the overall offshoring intensity are interpolated for missing years.

For years beyond 2000, the OECD data were extended using the latest input-output table available (2000 for most countries) and updating the data on the import proportions for each category of intermediate input. The latter was approximated by the share of imports in domestic absorption (consumption and investment) for that category of products (sector). Data on imports by sectors are from the OECD STAN Industrial Database for manufacturing and from the OECD International Trade in Services Database for services. Data on value added by sector (used to calculate absorption) are from a combination of the OECD STAN Industrial Database and the Groningen 60-industry Database. ${ }^{34}$

Imports of final goods and services are constructed as a residual by subtracting imported intermediate inputs from total imports.

\footnotetext{
${ }^{34}$ Sectoral offshoring intensities were aggregated using sectoral value-added weights, due to the lack of data on sectoral gross output for the later years. The historical and extended series were then spliced using growth rates.
} 


\section{Global Labor Supply}

Several measures of the global labor supply are calculated, including the world's working-age population, the world's labor force, and an export-weighted world's labor force. The latter attempts to measure the presence of the countries' labor supply in the international market and is calculated as the sum across countries of national labor forces, each weighted by the country's ratio of non-oil exports to GDP (Harrigan and Balaban, 1999). The export-to-GDP ratio is capped to one to limit the weight of countries specialized in re-export trade. Data on working-age population and labor force are from various sources, including the World Economic Outlook, the World Bank’s World Development Indicators, the United Nations Population Projections, and the CEIC Asia databases. The global labor supply by education level is calculated using the Barro-Lee (2000) dataset on educational attainment of the population aged 15 or more. It is assumed that the share of the labor force with higher education is about the same as the share of the population aged 15 or more with higher education. For the years 2001-05, this share was extrapolated linearly for each country.

The projections of the global labor supply for 2006-50 are based on the UN projections of the working-age population. The labor force participation rate in each country is assumed to converge by 2050 to the current rate of labor force participation in the United States. Assuming instead that labor force participation rates remain at their current levels does not have much effect on the global labor supply projections. Projections for the export-to-GDP ratio are based on World Economic Outlook projections until 2012, and on the trend increase observed in the world export-to-GDP ratio for later years. Under these assumptions, the cumulative growth in the export-weighted global labor force over 2005-50 could range from a low of 120 percent (under the low variant of the population projections) to a high of 190 percent (under the high variant).

\section{Capital Stock and ICT Capital}

Fajnzylber and Lederman (1999) is the source of the capital stock series for the entire economy. This dataset extends the capital stock series estimated by Nehru and Dhareshwar (1993) by adding the annual flow of gross fixed capital formation and assuming a 4 percent depreciation rate to the preexisting stock of capital. Fajnzylber and Lederman (1999) was further updated to recent years using the same methodology.

Jorgensen and $\mathrm{Vu}$ (2005) provides series on IT investment using national expenditure data for computer hardware, software, and telecommunications equipment. A perpetual inventory method applies varying depreciation rates to estimate the IT capital stock. This method assumes a geometric depreciation rate of 31.5 percent and a service life of 7 years for computer hardware, 31.5 percent and 5 years for software, and 11 percent and 11 years for telecommunications equipment.

\section{Labor Market Policies Indicators}

The indicators of labor and product market policies were provided by Bassanini and Duval (2006). The indicators are defined as follows: 
- $\quad$ Average unemployment benefit replacement rate is the average of the unemployment benefit replacement rates corresponding to multiple income, family, and unemployment duration situations. These include two income situations (100 percent and 67 percent of the average production worker earnings), three family situations (single, with dependent spouse, with spouse in work), and three unemployment durations (1st year, 2nd and 3rd years, and 4th and 5th years of unemployment). The original data are from the OECD Benefits and Wages Database.

- Labor tax wedge is the difference between the labor cost to the employer and the corresponding net take-home pay of the employee for a single-earner couple with two children earning 100 percent of the average production worker earnings. It is thus the sum of personal income tax and all social security contributions expressed as a percentage of the total labor cost. The original data are from the OECD Taxing Wages Database.

- $\quad$ Employment protection legislation is the OECD summary indicator of the stringency of Employment Protection Legislation. The original data are from the $O E C D$ Employment Outlook (2004).

- $\quad$ Product market regulation is the OECD summary indicator of regulatory impediments to product market competition in seven nonmanufacturing industries (gas, electricity, post, telecom, passenger air transport, railways passenger and freight services, and road freight). The original data are from Conway and others (2006).

- $\quad$ Union density measures the share of workers affiliated with a trade union. The original data are from the OECD Employment Outlook (2004). 


\section{APPENDIX II. DERIVATION OF THE EMPIRICAL MODEL}

The basic model used in this paper follows the recent trade literature (see Feenstra, 2004; Harrigan, 1998; and Kohli, 1991) that employs an (economy-wide) translog revenue function with fixed factor quantities (of labor and capital) and exogenous product prices (of exports, imports, and domestic absorption):

$$
\begin{aligned}
\ln G & =\theta_{0}+\sum \alpha_{i} \ln p_{i}+\sum \beta_{i} \ln v_{i}+\frac{1}{2} \sum \sum \alpha_{i j} \ln p_{i} \ln p_{j}+\frac{1}{2} \sum \sum \beta_{i j} \ln v_{i} \ln v_{j}+ \\
& +\sum \sum \gamma_{i j} \ln p_{i} \ln v_{j}+\sum \delta_{j} z_{j}+\sum \sum \varphi_{i j} \ln p_{i} z_{j}+\sum \sum \phi_{i j} \ln v_{i} z_{j},
\end{aligned}
$$

where $p$ are product prices, $v$ are factor quantities, and $z$ are shift variables capturing any factors that could be expected to shift the revenue function. It is assumed that this function is symmetric and linearly homogeneous in product prices and factor quantities. Symmetry requires that $\alpha_{i j}=\alpha_{j i}$ and $\beta_{i j}=\beta_{j i}$. Linear homogeneity in product prices requires that $\sum \alpha_{i}=1$ and $\sum \alpha_{i j}=\sum \gamma_{i j}=0$, and linear homogeneity in factor quantities requires that $\sum \beta_{i}=1$ and $\sum \beta_{i j}=\sum \gamma_{j i}=0$.

The output and input share equations - output supply and (inverse) input demand equations in share form - are obtained by differentiating the above function with respect to, respectively, prices and quantities:

$$
\begin{aligned}
& S_{i}=\frac{p_{i} y_{i}}{G}=\frac{\partial \ln G}{\partial \ln p_{i}}=\alpha_{i}+\sum \alpha_{i j} \ln p_{j}+\sum \gamma_{i j} \ln v_{j}+\sum \varphi_{i j} z_{j} \\
& R_{i}=\frac{w_{i} v_{i}}{G}=\frac{\partial \ln G}{\partial \ln v_{i}}=\beta_{i}+\sum \gamma_{j i} \ln p_{j}+\sum \beta_{i j} \ln v_{j}+\sum \phi_{i j} z_{j},
\end{aligned}
$$

where $S$ are output shares and $R$ are input shares. Since the focus of the paper is on the labor share, only the second of these equations is used and augmented by the following shifters of the revenue function $z$ : the intensity of offshoring, the share of immigrants in the domestic labor force, the share of ICT capital in total capital (and its square), and measures of labor market policies (specifically, the tax wedge, the replacement rate of unemployment benefits, indices of product market regulation, employment protection legislation, and union density). To impose the linear homogeneity restrictions, the labor share equation is expressed in terms of relative prices and quantities, giving rise to the following estimating equation:

$$
R_{L}=\beta_{L}+\gamma_{E L} \ln \frac{p_{E}}{p_{A}}+\gamma_{M L} \ln \frac{p_{M}}{p_{A}}+\beta_{L L} \ln \frac{L}{K}+\phi_{L X} X+\phi_{L M} \frac{L_{M}}{L}+\phi_{L C} \frac{K_{I C T}}{K}+\phi_{L C 2}\left(\frac{K_{I C T}}{K}\right)^{2}+\phi_{L P} L M P+\varepsilon_{L},
$$

where $P_{E}, P_{M}$, and $P_{A}$ are prices of exports, imports, and absorption, $L$ is labor; $K$ is capital; $X$ is the intensity of offshoring; $L_{M}$ is immigrant employment; $K_{I C T}$ is ICT capital, and $L M P$ are labor market policies. 
Labor share equations for workers in skilled and unskilled sectors are derived in the same way as the overall labor share equation from the revenue function with three factors labor in skilled sectors, labor in unskilled sectors, and capital - giving rise to the following system:

$$
\begin{aligned}
& R_{S}=\beta_{S}+\sum_{k=E, M} \gamma_{k S} \ln \frac{p_{k}}{p_{A}}+\sum_{k=S, U} \beta_{S k} \ln \frac{L_{k}}{K}+\phi_{S X} X+\phi_{S M} \frac{L_{M}}{L}+\phi_{S C} \frac{K_{I C T}}{K}+\phi_{S C 2}\left(\frac{K_{I C T}}{K}\right)^{2}+\phi_{S P} L M P+\varepsilon_{S} \\
& R_{U}=\beta_{U}+\sum_{k=E, M} \gamma_{k U} \ln \frac{p_{k}}{p_{A}}+\sum_{k=S, U} \beta_{U k} \ln \frac{L_{k}}{K}+\phi_{U X} X+\phi_{U M} \frac{L_{M}}{L}+\phi_{U C} \frac{K_{I C T}}{K}+\phi_{U C 2}\left(\frac{K_{I C T}}{K}\right)^{2}+\phi_{U P} L M P+\varepsilon_{U},
\end{aligned}
$$

where $S$ and $U$ denote skilled and unskilled sectors, respectively, and the other variables are the same as above. Symmetry implies that $\beta_{S U}=\beta_{U S}$, i.e. the coefficients on the (log of) labor-capital ratio of the unskilled sectors in the first equation and of the skilled sectors in the second equation are the same.

The econometric model just described allows going beyond the effects of various factors on the labor share by computing the elasticities of labor compensation per worker and employment to trade prices. The short-run elasticities of labor compensation per worker to trade prices (given employment) are obtained as follows:

$$
\gamma_{i L}=\frac{\partial R_{L}}{\partial \ln p_{i}}=R_{L} \varepsilon\left(W, p_{i}\right)-R_{L} S_{i} \Rightarrow \varepsilon\left(W, p_{i}\right)=\frac{\gamma_{i L}}{R_{L}}+S_{i},
$$

where $i=E$ (exports), $M$ (imports) and the shares $R_{L}$ and $S_{i}$ are evaluated at the sample mean for each country. The long-run employment elasticities with respect to trade prices (given labor compensation per worker) are obtained from the relevant sub-matrices of the matrix of short-run elasticities $E$ :

$$
\varepsilon\left(W, p_{i}\right)=\left.E_{W p}\right|_{i} \Rightarrow \varepsilon\left(L, p_{i}\right)=-\left.E_{W L}^{-1} E_{W p}\right|_{i}=-\frac{\varepsilon\left(W, p_{i}\right)}{\varepsilon(W, L)},
$$

where $\varepsilon(W, L)=\frac{\beta_{L L}}{R_{L}}+R_{L}-1$ and $i=E$ (exports), $M$ (imports). ${ }^{35}$

\footnotetext{
${ }^{35}$ See Kohli (1991) for more detail. It is important to point out that these elasticities are derived from the model that assumes fixed prices, hence possible price adjustments are not taken into account in these calculations.
} 


\section{Table 1. Impact of Labor Globalization and Technological Change on Labor Shares: Main Results}

\begin{tabular}{|c|c|c|c|c|}
\hline $\begin{array}{l}\text { Dependent Variable: } \\
\text { Labor Share }\end{array}$ & $\begin{array}{l}\text { OLS Estimation } \\
\text { Excluding Labor } \\
\text { Market Policies } \\
\text { (1) } \\
\end{array}$ & $\begin{array}{l}\text { OLS Estimation } \\
\text { Including all Labor } \\
\text { Market Policies } \\
\text { (2) }\end{array}$ & $\begin{array}{l}\text { OLS Estimation } \\
\text { Preferred Model } \\
\\
\text { (3) } \\
\end{array}$ & $\begin{array}{c}\text { Instrumental } \\
\text { Variables } \\
\text { Estimation } \\
\text { Preferred Model } \\
\text { (4) } \\
\end{array}$ \\
\hline Relative export price (log of) & $\begin{array}{l}-0.120 \\
(3.20)^{* * *}\end{array}$ & $\begin{array}{l}-0.117 \\
(3.17)^{* * *}\end{array}$ & $\begin{array}{l}-0.117 \\
(3.22)^{* * *}\end{array}$ & $\begin{array}{l}-0.165 \\
(5.42)^{* * *}\end{array}$ \\
\hline Relative import price (log of) & $\begin{array}{r}0.060 \\
(1.56)\end{array}$ & $\begin{array}{l}0.079 \\
(2.32)^{* *}\end{array}$ & $\begin{array}{l}0.083 \\
(2.47)^{* *}\end{array}$ & $\begin{array}{l}0.123 \\
(3.06)^{* * *}\end{array}$ \\
\hline Labor-capital ratio (log of) & $\begin{array}{c}0.051 \\
(1.77)^{*}\end{array}$ & $\begin{array}{r}0.009 \\
(0.28)\end{array}$ & $\begin{array}{r}0.006 \\
(0.18)\end{array}$ & $\begin{array}{l}-0.02 \\
(0.58)\end{array}$ \\
\hline Offshoring & $\begin{array}{l}-0.190 \\
(2.02)^{*}\end{array}$ & $\begin{array}{l}-0.215 \\
(2.40)^{* *}\end{array}$ & $\begin{array}{l}-0.197 \\
(2.52)^{* *}\end{array}$ & $\begin{array}{l}-0.234 \\
(2.63)^{* * *}\end{array}$ \\
\hline Immigration & $\begin{array}{l}-0.762 \\
(3.63)^{* * *}\end{array}$ & $\begin{array}{l}-0.610 \\
(3.57)^{* * *}\end{array}$ & $\begin{array}{l}-0.629 \\
(3.75)^{* * *}\end{array}$ & $\begin{array}{l}-0.824 \\
(5.00)^{* * * *}\end{array}$ \\
\hline ICT capital & $\begin{array}{l}-2.624 \\
(2.98)^{* * *}\end{array}$ & $\begin{array}{l}-2.388 \\
(1.59)\end{array}$ & $\begin{array}{l}-2.902 \\
(3.19)^{* * *}\end{array}$ & $\begin{array}{l}-3.408 \\
(4.26)^{* * *}\end{array}$ \\
\hline ICT capital squared & $\begin{array}{l}49.628 \\
(3.06)^{* * *}\end{array}$ & $\begin{array}{c}38.864 \\
(1.71)\end{array}$ & $\begin{array}{l}47.504 \\
(3.11)^{* * *}\end{array}$ & $\begin{array}{l}53.001 \\
(3.61)^{* * *}\end{array}$ \\
\hline Tax wedge & & $\begin{array}{l}-0.002 \\
(3.22)^{* * * *}\end{array}$ & $\begin{array}{l}-0.002 \\
(2.80)^{* *}\end{array}$ & $\begin{array}{l}-0.002 \\
(3.41)^{* * * *}\end{array}$ \\
\hline Unemployment benefits & & $\begin{array}{l}-0.001 \\
(3.98)^{* * * *}\end{array}$ & $\begin{array}{l}-0.001 \\
(5.15)^{* * *}\end{array}$ & $\begin{array}{l}-0.001 \\
(5.09)^{* * *}\end{array}$ \\
\hline Product market regulation & & $\begin{array}{l}0.004 \\
(0.70)\end{array}$ & & \\
\hline $\begin{array}{l}\text { Employment protection } \\
\text { legislation }\end{array}$ & & $\begin{array}{l}-0.001 \\
(0.14)\end{array}$ & & \\
\hline Union density & & $\begin{array}{l}-0.001 \\
(0.81)\end{array}$ & & \\
\hline Fixed effects (demeaning) & Yes & Yes & Yes & Yes \\
\hline Time dummies & Yes & Yes & Yes & Yes \\
\hline $\begin{array}{l}\text { Observations } \\
\text { Adjusted } R \text {-squared } \\
\text { Anderson test } \\
\text { Hansen test ( } p \text {-value) }\end{array}$ & $\begin{array}{l}208 \\
0.63\end{array}$ & $\begin{array}{l}208 \\
0.68\end{array}$ & $\begin{array}{l}208 \\
0.68\end{array}$ & $\begin{array}{l}208 \\
155.07^{* * *} \\
0.19\end{array}$ \\
\hline \multicolumn{5}{|c|}{$\begin{array}{l}\text { Source: IMF staff calculations. } \\
\text { Note: Heteroskedasticity and autocorrelation robust t-statistics are in parentheses.* denotes statistical significance at the } \\
10 \text { percent level; ** denotes statistical significance at the } 5 \text { percent level; and } * * * \text { denotes statistical significance at the } 1 \text { percent } \\
\text { level. The left-hand side and right-hand side variables are demeaned using country-specific means (equivalent to doing a panel } \\
\text { estimation with fixed effects) and time dummies are included in the equations. The instrumental variable estimation in column (4) } \\
\text { instruments for the (logs of) relative export and import prices, offshoring and immigration using as instruments the lagged value of } \\
\text { these variables, the share of government consumption in GDP, the consumption tax rate, the (log of) total population, the (log of) } \\
\text { export-weighted real GDP of trading partners, and the distance-weighted, export-adjusted employment in the rest of the world. } \\
\text { ICT = information and communications technology. }\end{array}$} \\
\hline
\end{tabular}


Table 2. Impact of Labor Globalization and Technological Change on Labor Shares: Alternative Specifications

\begin{tabular}{|c|c|c|c|c|}
\hline $\begin{array}{l}\text { Dependent Variable: } \\
\text { Labor Share }\end{array}$ & $\begin{array}{l}\text { IV Estimation } \\
\text { ICT Investment } \\
\text { (1) }\end{array}$ & $\begin{array}{l}\text { IV Estimation } \\
\text { Oil and Non-Oil } \\
\text { Import Price } \\
\text { (2) }\end{array}$ & $\begin{array}{c}\text { IV Estimation } \\
\text { Offshoring of Skilled } \\
\text { and Unskilled Inputs } \\
\text { (3) }\end{array}$ & $\begin{array}{l}\text { IV Estimation } \\
\text { Financial } \\
\text { Openness } \\
(4)\end{array}$ \\
\hline Relative export price (log of) & $\begin{array}{l}-0.156 \\
(5.27)^{* * *}\end{array}$ & $\begin{array}{l}-0.17 \\
(4.40)^{* * *}\end{array}$ & $\begin{array}{l}-0.145 \\
(4.68)^{* * *}\end{array}$ & $\begin{array}{l}-0.162 \\
(5.43)^{* * *}\end{array}$ \\
\hline Relative import price (log of) & $\begin{array}{l}0.125 \\
(3.39)^{* * *}\end{array}$ & & $\begin{array}{l}0.107 \\
(2.65)^{* * *}\end{array}$ & $\begin{array}{l}0.115 \\
(2.92)^{* * * *}\end{array}$ \\
\hline Oil & & $\begin{array}{r}0.002 \\
(0.23)\end{array}$ & & \\
\hline Non-Oil & & $\begin{array}{l}0.131 \\
(2.11)^{* *}\end{array}$ & & \\
\hline Labor-capital ratio (log of) & $\begin{array}{l}-0.032 \\
(0.94)\end{array}$ & $\begin{array}{l}-0.008 \\
(0.21)\end{array}$ & $\begin{array}{l}0 \\
(0.00)\end{array}$ & $\begin{array}{l}-0.004 \\
(0.10)\end{array}$ \\
\hline Offshoring & $\begin{array}{l}-0.216 \\
(2.13)^{* *}\end{array}$ & $\begin{array}{l}-0.263 \\
(2.46)^{* *}\end{array}$ & & $\begin{array}{l}-0.232 \\
(3.11)^{* * *}\end{array}$ \\
\hline Skilled inputs & & & $\begin{array}{l}-0.476 \\
(2.77)^{* * *}\end{array}$ & \\
\hline Unskilled inputs & & & $\begin{array}{c}0.27 \\
(0.85)\end{array}$ & \\
\hline Immigration & $\begin{array}{l}-0.879 \\
(5.22)^{* * *}\end{array}$ & $\begin{array}{l}-0.712 \\
(4.43)^{* * *}\end{array}$ & $\begin{array}{l}-0.767 \\
(4.19)^{* * *}\end{array}$ & $\begin{array}{l}-0.839 \\
(5.74)^{* * *}\end{array}$ \\
\hline ICT capital & $\begin{array}{l}-0.939 \\
(3.70)^{* * *}\end{array}$ & $\begin{array}{l}-3.106 \\
(3.63)^{* * *}\end{array}$ & $\begin{array}{l}-2.247 \\
(1.93)^{*}\end{array}$ & $\begin{array}{l}-2.724 \\
(2.22)^{* *}\end{array}$ \\
\hline ICT capital squared & $\begin{array}{l}3.307 \\
(3.24)^{* * *}\end{array}$ & $\begin{array}{l}49.874 \\
(3.07)^{* * *}\end{array}$ & $\begin{array}{l}37.92 \\
(1.93)^{*}\end{array}$ & $\begin{array}{l}44.464 \\
(2.31)^{* *}\end{array}$ \\
\hline Tax wedge & $\begin{array}{l}-0.002 \\
(3.74)^{* * *}\end{array}$ & $\begin{array}{l}-0.002 \\
(3.41)^{* * *}\end{array}$ & $\begin{array}{l}-0.003 \\
(3.20)^{* * *}\end{array}$ & $\begin{array}{l}-0.002 \\
(3.26)^{* * *}\end{array}$ \\
\hline Unemployment benefits & $\begin{array}{l}-0.001 \\
(6.14)^{* * *}\end{array}$ & $\begin{array}{l}-0.001 \\
(4.77)^{* * *}\end{array}$ & $\begin{array}{l}-0.001 \\
(5.54)^{* * *}\end{array}$ & $\begin{array}{l}-0.001 \\
(4.74)^{* * *}\end{array}$ \\
\hline Financial Openness & & & & $\begin{array}{l}-0.003 \\
(0.87)\end{array}$ \\
\hline Fixed effects (demeaning) & Yes & Yes & Yes & Yes \\
\hline Time dummies & Yes & Yes & Yes & Yes \\
\hline $\begin{array}{l}\text { Observations } \\
\text { Anderson test } \\
\text { Hansen test ( } p \text {-value) }\end{array}$ & $\begin{array}{l}208 \\
158.09^{* * *} \\
0.14\end{array}$ & $\begin{array}{l}208 \\
119.73^{* * * *} \\
0.13\end{array}$ & $\begin{array}{l}208 \\
128.63^{* * *} \\
0.19\end{array}$ & $\begin{array}{l}208 \\
96.96^{* * *} \\
0.16\end{array}$ \\
\hline \multicolumn{5}{|c|}{$\begin{array}{l}\text { Source: IMF staff calculations. } \\
\text { Note: Heteroskedasticity and autocorrelation robust t-statistics are in parentheses. * denotes statistical significance at the } \\
10 \text { percent level; ** denotes statistical significance at the } 5 \text { percent level; and *** denotes statistical significance at the } 1 \text { percent } \\
\text { level. The left-hand side and right-hand side variables are demeaned using country-specific means (equivalent to doing a panel } \\
\text { estimation with fixed effects) and time dummies are included in the equations. The instrumental variable estimation instruments } \\
\text { for the (logs of) relative export and import prices, offshoring and immigration using as instruments the lagged value of these } \\
\text { variables, the share of government consumption in GDP, the consumption tax rate, the (log of) total population, the (log of) export- } \\
\text { weighted real GDP of trading partners, and the distance-weighted, export-adjusted employment in the rest of the world. In column } \\
\text { (4), financial openness is also instrumented by the distance-weighted financial openness in the rest of the world. ICT capital } \\
\text { denotes the share of information and communications technology capital in the total capital stock, except in column (1) where it } \\
\text { denotes the share of information and communications technology investment in total investment. }\end{array}$} \\
\hline
\end{tabular}




\section{Table 3. Impact of Labor Globalization and Technological Change on} Skilled and Unskilled Labor Shares

\begin{tabular}{|c|c|c|c|c|}
\hline \multirow[b]{2}{*}{ Dependent Variable } & \multicolumn{2}{|c|}{$\begin{array}{c}\text { Seemingly Unrelated Regressions } \\
\text { Estimator } \\
\end{array}$} & \multicolumn{2}{|c|}{$\begin{array}{c}\text { Three-Stage Least Squares } \\
\text { Estimator } \\
\end{array}$} \\
\hline & $\begin{array}{c}\text { Skilled labor share } \\
\text { (1) }\end{array}$ & $\begin{array}{c}\text { Unskilled } \\
\text { labor share } \\
(2)\end{array}$ & $\begin{array}{c}\text { Skilled labor } \\
\text { share } \\
(3) \\
\end{array}$ & $\begin{array}{c}\text { Unskilled } \\
\text { labor share } \\
(4)\end{array}$ \\
\hline \multicolumn{5}{|l|}{ Log of: } \\
\hline Relative export price (log of) & $\begin{array}{l}-0.068 \\
(5.75)^{* * *}\end{array}$ & $\begin{array}{l}-0.048 \\
(6.79)^{* * *}\end{array}$ & $\begin{array}{l}-0.110 \\
(6.49)^{* * *}\end{array}$ & $\begin{array}{l}-0.060 \\
(6.11)^{* * *}\end{array}$ \\
\hline Relative import price (log of) & $\begin{array}{l}0.050 \\
(4.34)^{* * *}\end{array}$ & $\begin{array}{l}0.035 \\
(5.11)^{* * *}\end{array}$ & $\begin{array}{l}0.085 \\
(5.32)^{* * *}\end{array}$ & $\begin{array}{l}0.044 \\
(4.78)^{* * *}\end{array}$ \\
\hline $\begin{array}{l}\text { Skilled labor-capital ratio } \\
\text { (log of) }\end{array}$ & $\begin{array}{c}0.177 \\
(12.21)^{* * *}\end{array}$ & $\begin{array}{l}-0.161 \\
(18.23)^{* * *}\end{array}$ & $\begin{array}{c}0.162 \\
(10.21)^{* * *}\end{array}$ & $\begin{array}{c}-0.165 \\
(17.72)^{* * *}\end{array}$ \\
\hline $\begin{array}{l}\text { Unskilled labor-capital ratio } \\
\text { (log of) }\end{array}$ & $\begin{array}{l}-0.161 \\
(18.23)^{* * *}\end{array}$ & $\begin{array}{c}0.144 \\
(21.38)^{* * *}\end{array}$ & $\begin{array}{l}-0.165 \\
(17.72)^{* * *}\end{array}$ & $\begin{array}{c}0.143 \\
(20.35)^{* * *}\end{array}$ \\
\hline Offshoring & $\begin{array}{l}-0.159 \\
(3.26)^{* * *}\end{array}$ & $\begin{array}{l}-0.035 \\
(1.22)\end{array}$ & $\begin{array}{l}-0.177 \\
(3.04)^{* * *}\end{array}$ & $\begin{array}{l}-0.040 \\
(1.20)\end{array}$ \\
\hline Immigration & $\begin{array}{l}-0.496 \\
(5.19)^{* * *}\end{array}$ & $\begin{array}{l}-0.170 \\
(2.99)^{* * *}\end{array}$ & $\begin{array}{l}-0.660 \\
(5.53)^{* * * *}\end{array}$ & $\begin{array}{l}-0.230 \\
(3.33)^{* * *}\end{array}$ \\
\hline ICT capital & $\begin{array}{l}-1.612 \\
(3.73)^{* * *}\end{array}$ & $\begin{array}{l}-1.286 \\
(4.85)^{* * *}\end{array}$ & $\begin{array}{l}-1.923 \\
(4.21)^{* * *}\end{array}$ & $\begin{array}{l}-1.370 \\
(5.02)^{* * *}\end{array}$ \\
\hline ICT capital squared & $\begin{array}{l}33.154 \\
(5.12)^{* * *}\end{array}$ & $\begin{array}{l}16.493 \\
(4.19)^{* * *}\end{array}$ & $\begin{array}{l}36.473 \\
(5.38)^{* * *}\end{array}$ & $\begin{array}{l}17.405 \\
(4.33)^{* * *}\end{array}$ \\
\hline Tax wedge & $\begin{array}{l}-0.001 \\
(3.56)^{* * *}\end{array}$ & $\begin{array}{l}-0.001 \\
(4.34)^{* * *}\end{array}$ & $\begin{array}{l}-0.001 \\
(4.19)^{* * *}\end{array}$ & $\begin{array}{l}-0.001 \\
(4.58)^{* * *}\end{array}$ \\
\hline $\begin{array}{l}\text { Unemployment } \\
\text { benefits }\end{array}$ & $\begin{array}{l}-0.001 \\
(5.57)^{* * *}\end{array}$ & $\begin{array}{l}-0.000 \\
(4.17)^{* * *}\end{array}$ & $\begin{array}{l}-0.001 \\
(4.53)^{* * *}\end{array}$ & $\begin{array}{l}-0.000 \\
(3.55)^{* * *}\end{array}$ \\
\hline $\begin{array}{l}\text { Product market } \\
\text { regulation }\end{array}$ & $\begin{array}{r}0.000 \\
(0.08)\end{array}$ & $\begin{array}{c}0.002 \\
(2.20)^{* *}\end{array}$ & $\begin{array}{r}0.000 \\
(0.23)\end{array}$ & $\begin{array}{c}0.002 \\
(2.27)^{* *}\end{array}$ \\
\hline Fixed effects (demeaning) & Yes & Yes & Yes & Yes \\
\hline Time dummies & Yes & Yes & Yes & Yes \\
\hline Observations & 202 & 202 & 202 & 202 \\
\hline$R$-squared & 0.62 & 0.95 & 0.59 & 0.94 \\
\hline
\end{tabular}

Source: IMF staff calculations.

Note: $t$-statistics are in parentheses. * denotes statistical significance at the 10 percent level; ${ }^{* *}$ denotes statistical significance at the 5 percent level; and *** denotes statistical significance at the 1 percent level. The left-hand side and right-hand side variables are demeaned using country-specific means (equivalent to doing a panel estimation with fixed effects) and time dummies are included in the equations. The three-stage least squares estimator instruments for the (logs of) relative export and import prices, offshoring and immigration using as instruments the lagged value of these variables, the share of government consumption in GDP, the consumption tax rate, the (log of) total population, the (log of) export-weighted real GDP of trading partners, and the distance-weighted, exportadjusted employment in the rest of the world. ICT = information and communications technology. 
Table 4. Classification of Sectors by Skill Intensity

\begin{tabular}{ll}
\hline Main Classification & Alternative Classification \\
\hline & Low skilled \\
Unskilled & Agriculture \\
Agriculture & Mining \\
Mining & Food and tobacco \\
Food and tobacco & Textiles, apparel, and leather \\
Textiles, apparel, and leather & Wood \\
Wood & Other nonmetal products \\
Other nonmetal products & Metals and metal products \\
Metals and metal products & Construction \\
Transport equipment & \\
Other manufacturing & Medium skilled \\
Construction & Paper and publishing \\
Trade, hotels, and restaurants & Transport equipment \\
& Other manufacturing \\
Skilled & Utilities \\
Paper and publishing & Trade, hotels, and restaurants \\
Fuel, chemicals, and rubber & Transport and communications \\
Machinery and equipment & \\
Utilities & High skilled \\
Transport and communications & Fuel, chemicals, and rubber \\
Business services & Machinery and equipment \\
Social and personal services & Business services \\
& Social and personal services \\
& \\
\hline Sources: OECD; and & \\
\hline
\end{tabular}


Figure 1. Alternative Measures of Global Labor Supply
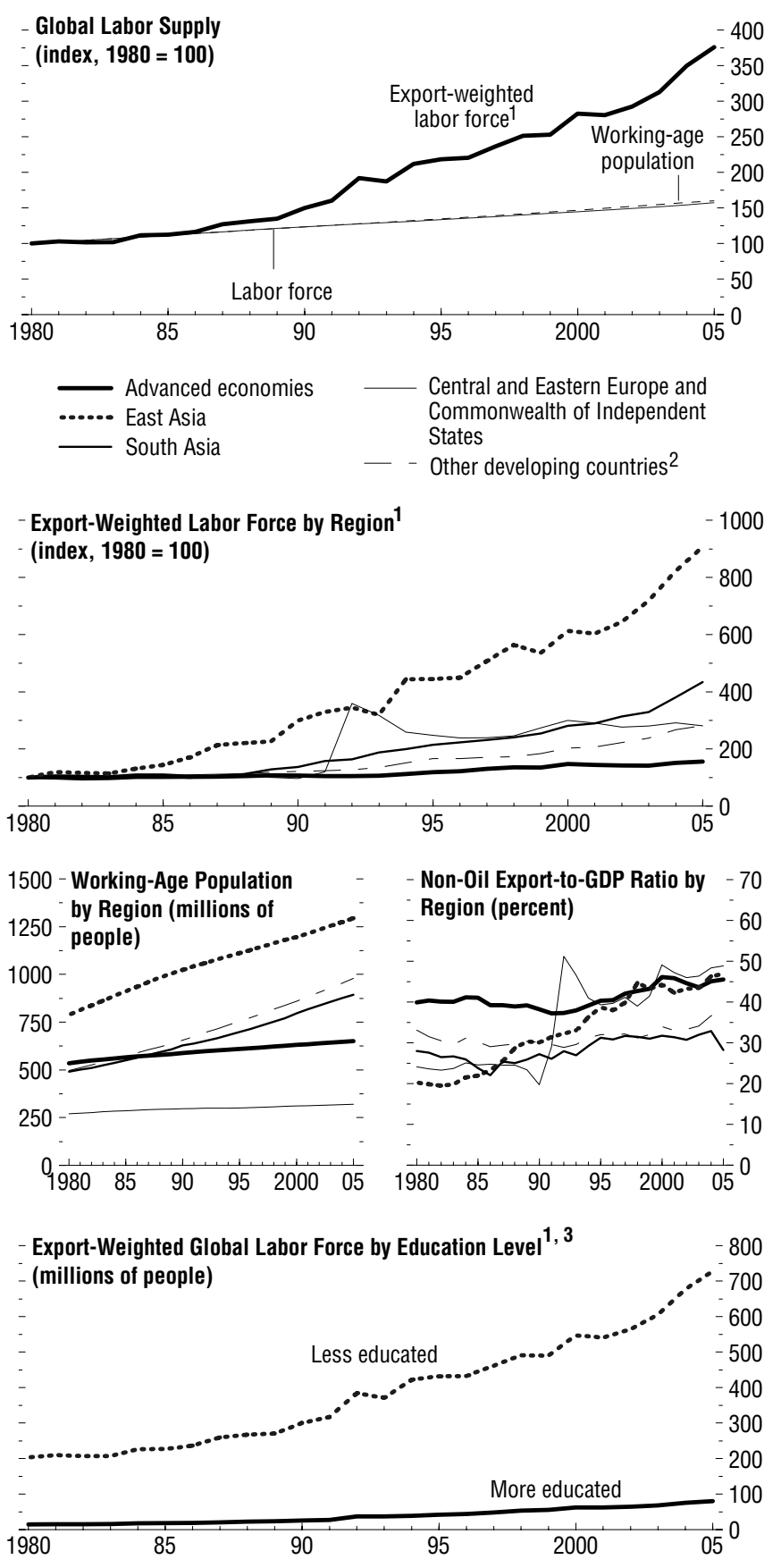

Sources: United Nations, Population Prospects: The 2004 Revision Population database; World Bank, World Development Indicators; and IMF staff calculations.

1 National labor forces scaled by export-to-GDP ratios.

${ }_{3}$ Includes Western Hemisphere, Middle East and North Africa, and sub-Saharan Africa.

More educated labor force is defined by persons with university-level education. Less educated is defined by labor force with primary and secondary education plus the uneducated. 
Figure 2. Immigration and Trade

(Percent of labor force and GDP, respectively)
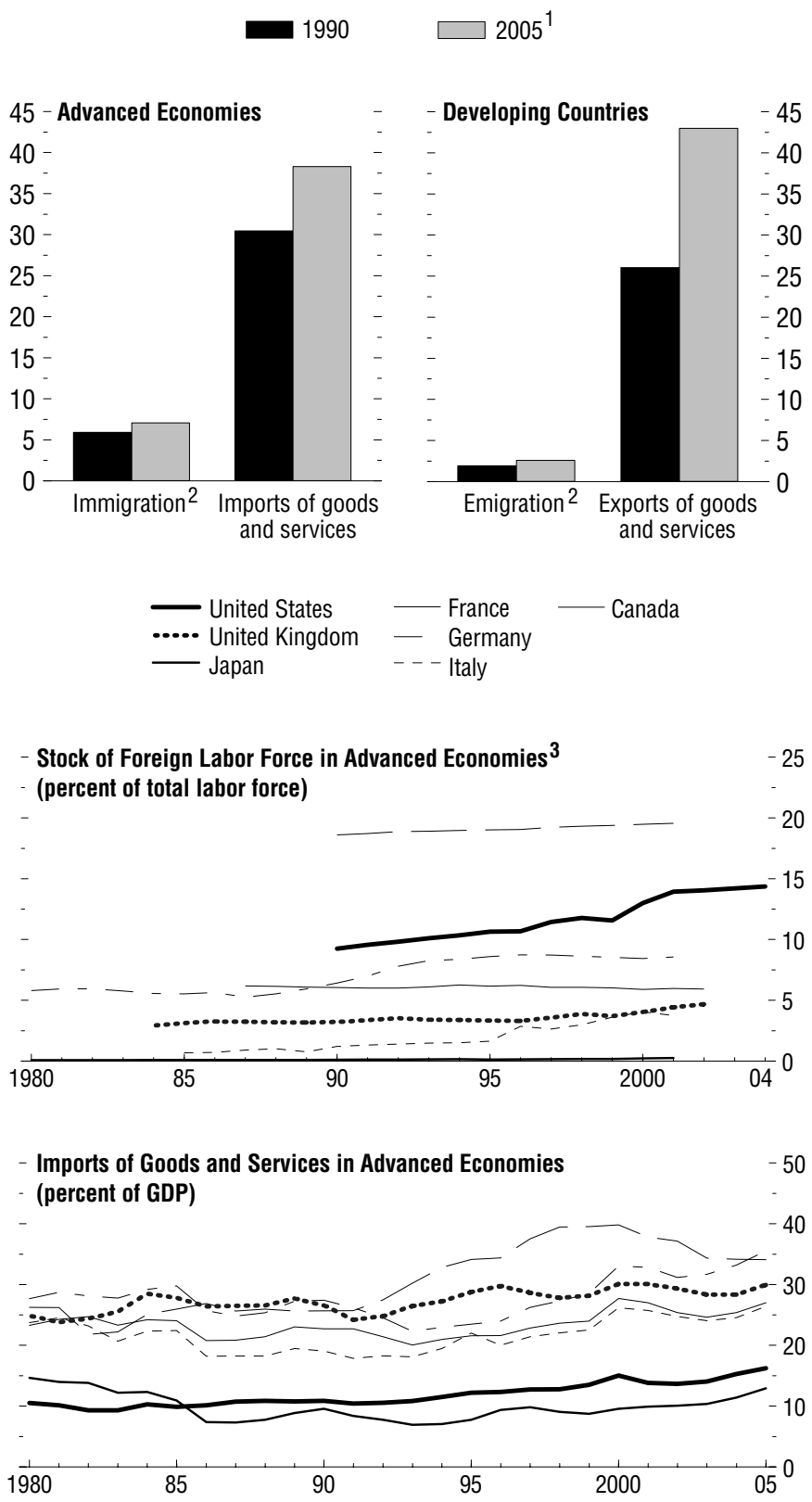

Sources: Docquier and Marfouk (2005); OECD, International Migration Data; U.S. Census Bureau; and IMF staff calculations.

12000 data for immigration and emigration.

${ }^{2}$ Hong Kong SAR, Greece, Israel, New Zealand, Singapore, and Taiwan Province of China are not included in average immigration due to data limitations. Russia and Slovak Republic are not included in average emigration due to data limitations.

${ }^{3}$ Foreign-born labor force for Australia, Canada, and the United States. For Italy, the Netherlands, Norway, and the United Kingdom, the data refer to the share of foreign employment in total employment. 
Figure 3. Change in the Share of Foreign Labor Force in Total Labor Force by Skill Level, 1990-2000 ${ }^{1,2}$

(Percentage points)

Primary

education

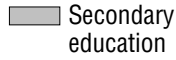

education $\square$ Tertiary

education
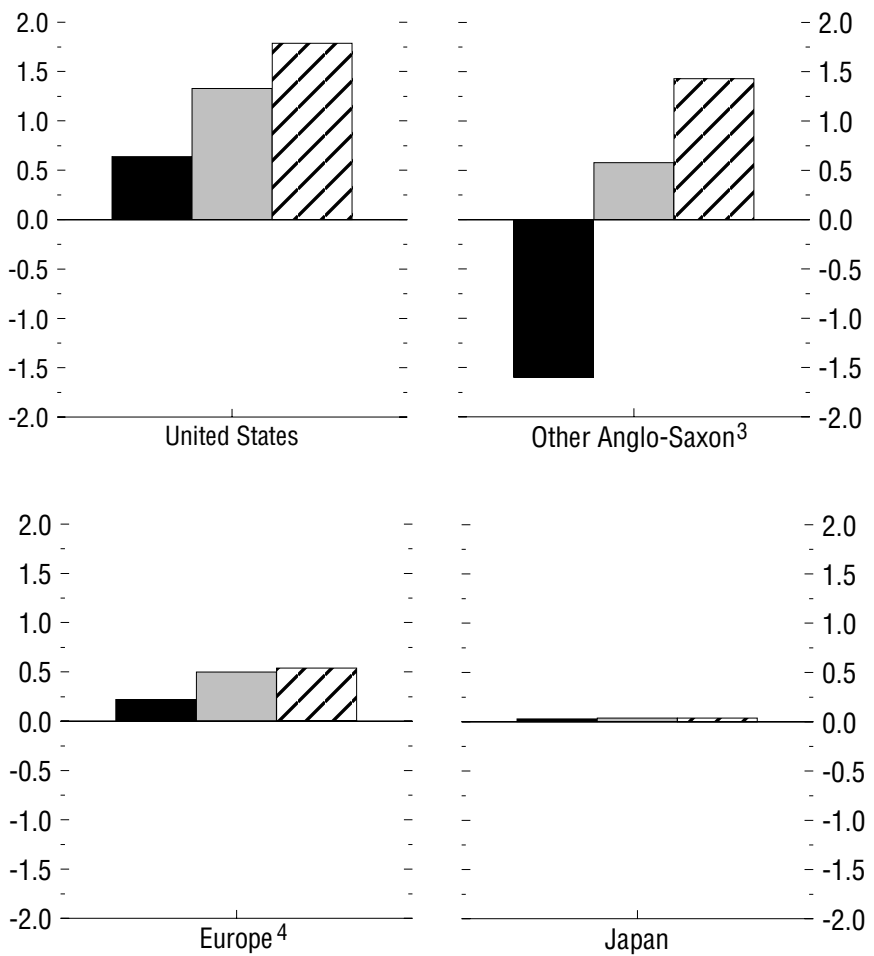

Sources: Docquier and Marfouk (2005); OECD, International Migration Data; U.S. Census Bureau; and IMF staff calculations.

1The stock of foreign labor force by skill level is calculated by applying the skill composition of the foreign population to the total stock of foreign labor force.

2Foreign-born labor force for Australia, Canada, and the United States. For Italy, the Netherlands, Norway, and the United Kingdom, the data refer to the share of foreign employment in total employment.

3 Other Anglo-Saxon countries include Australia, Canada, and the United Kingdom.

${ }^{4}$ Europe includes Austria, Belgium, Denmark, Finland, France, Germany, Ireland, Italy, the Netherlands, Norway, Portugal, Spain, Sweden, and Switzerland. 


\section{Figure 4. Share of Developing Countries in Trade}
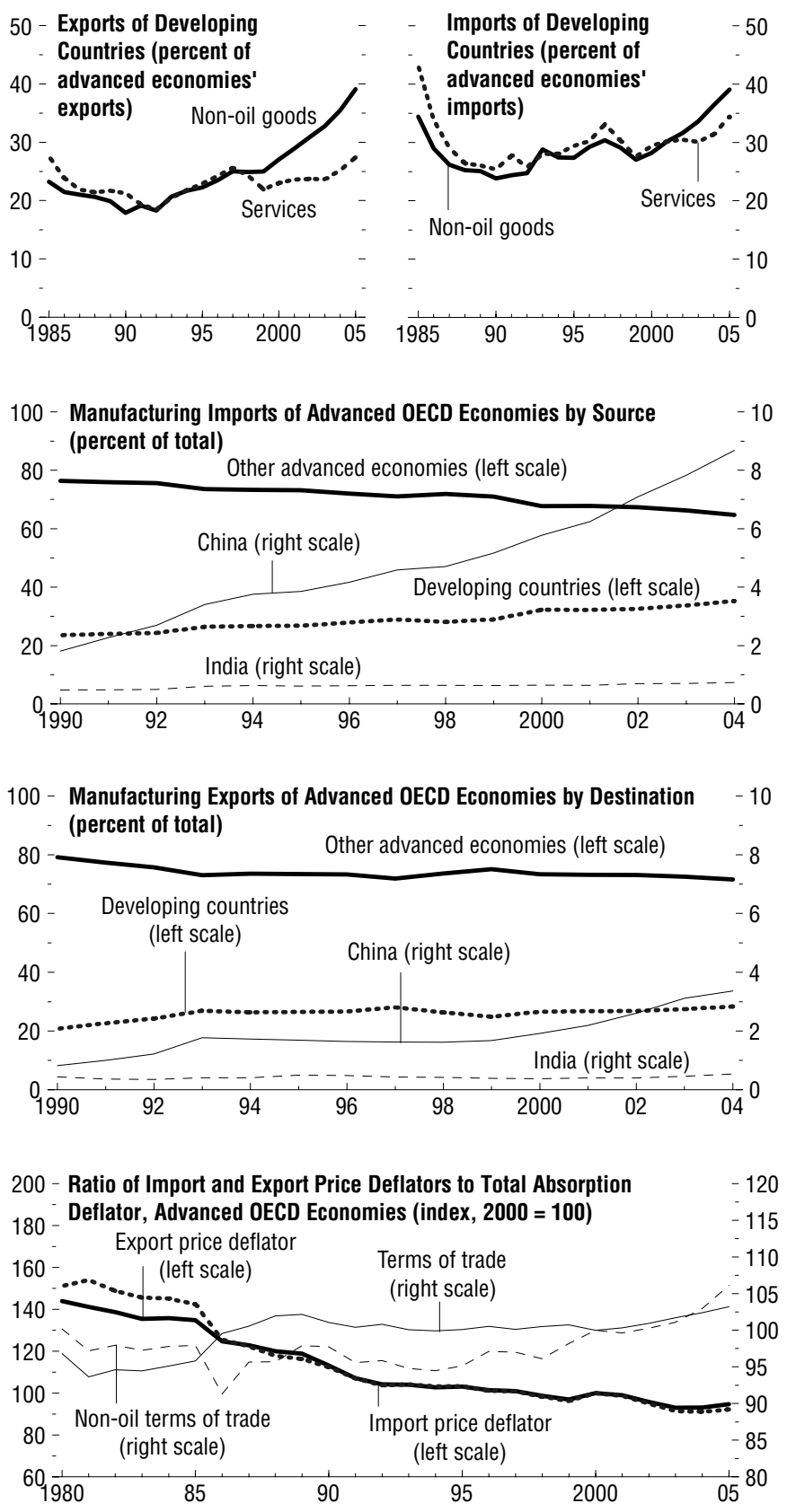

Sources: OECD, STAN Bilateral Trade Database; and IMF staff calculations. 


\section{Figure 5. Developing Countries: Exports of Skilled Manufacturing Goods and Services}

(Percent)
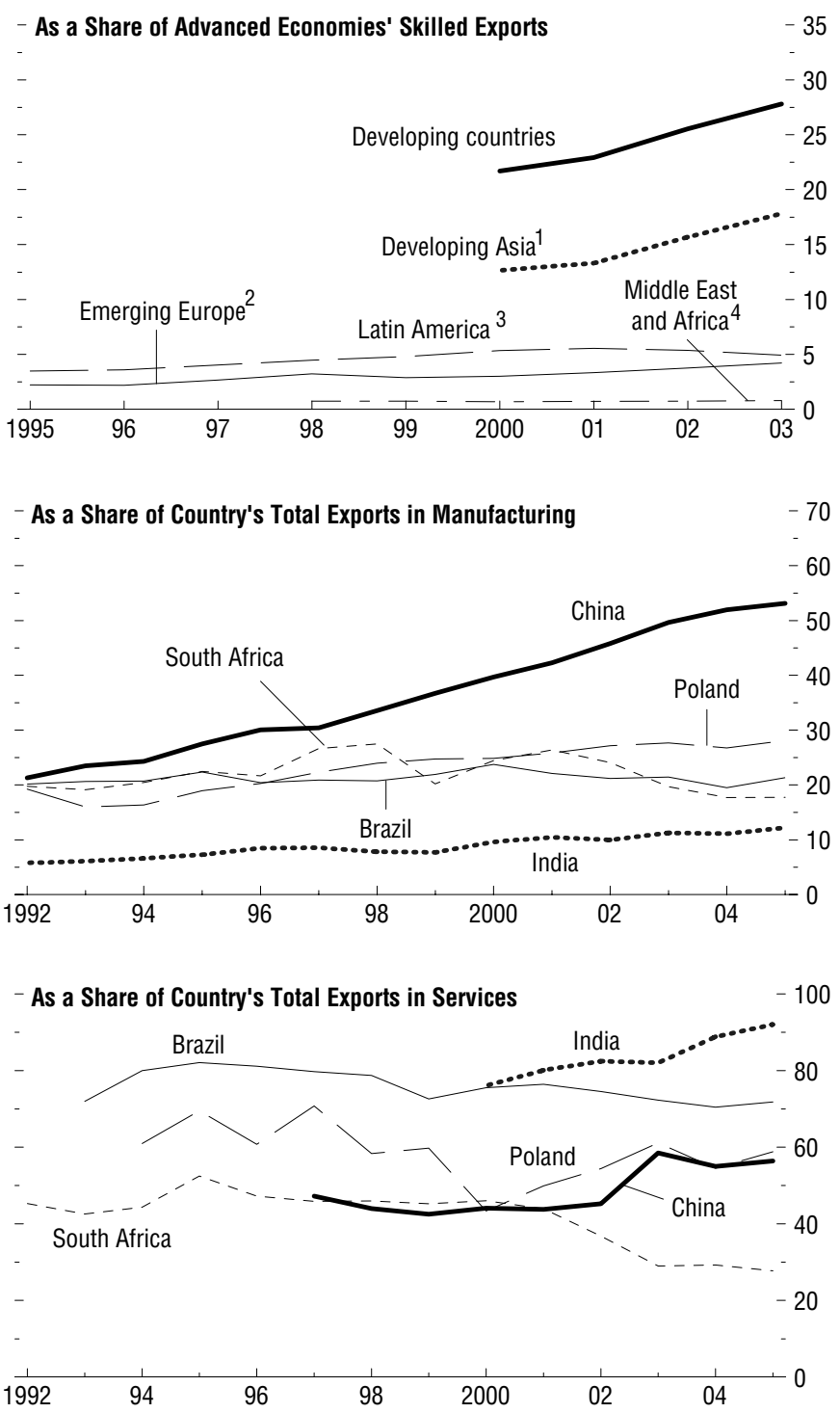

Sources: OECD, International Trade in Services Database and STAN Industrial

Database; World Bank, World Integrated Trade Solution database; and IMF, Balance of Payments Statistics.

1 Bangladesh, China, India, Malaysia, the Philippines, and Thailand.

${ }^{2}$ Czech Republic, Hungary, Poland, Romania, Slovak Republic, and Turkey.

${ }^{3}$ Argentina, Brazil, Chile, Colombia, Mexico, Peru, and Venezuela.

${ }^{4}$ Egypt, Ethiopia, Morocco, South Africa, Sudan, and Tanzania. 


\section{Figure 6. Offshoring by Advanced Economies ${ }^{1}$}

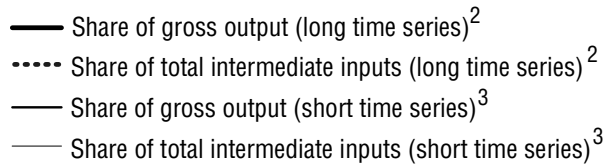

Total Offshoring in Advanced OECD Economies
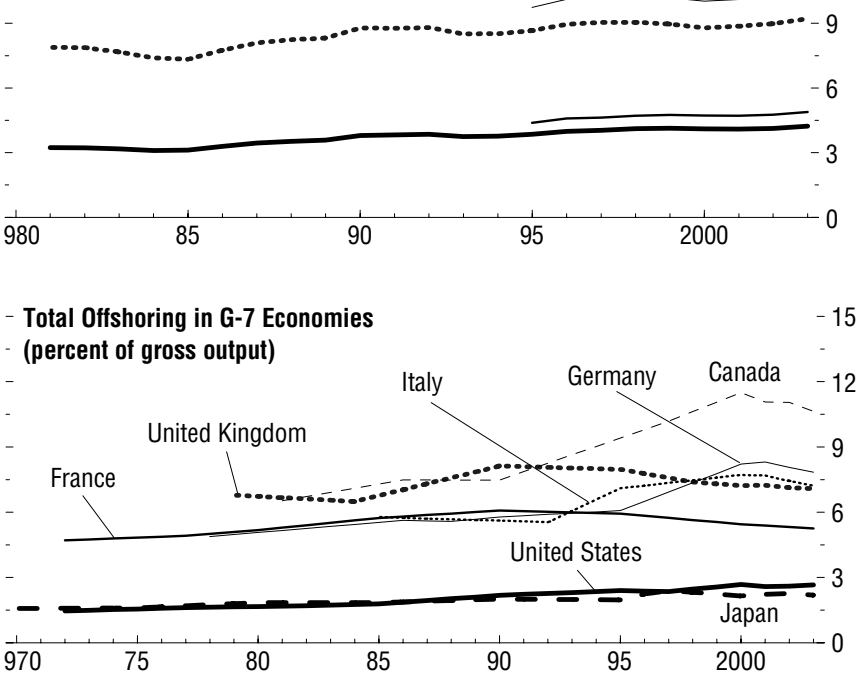

Total Offshoring in G-7 Economies

(percent of total imports of manufacturing goods and services)

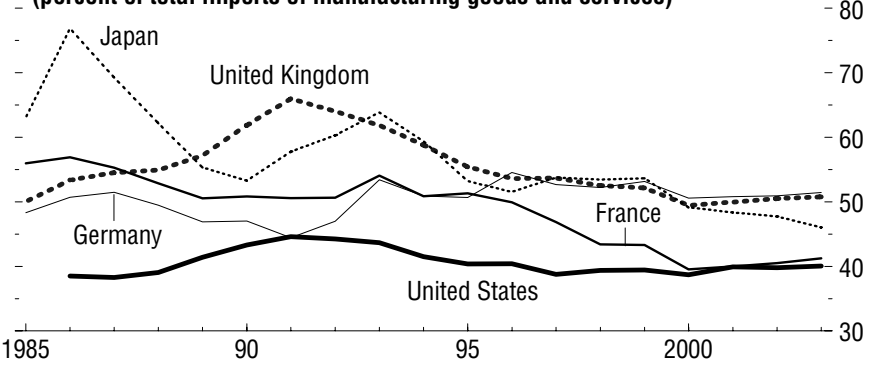

Sources: OECD, Input-Output Tables (1995, 2002, and 2006 editions), International Trade in Services Database, and STAN Industrial Database; Groningen Growth and Development Centre, 60-Industry Database (September 2006); and IMF staff calculations.

${ }^{1}$ Offshoring measures calculated using Input-Output Tables from OECD; resulting series extended from 2001 to 2003 by estimating extent of offshoring using a combination of data from the OECD STAN Industrial Database and the Groningen 60-Industry Database; only offshoring of nonenergy manufacturing and services inputs considered.

${ }^{2}$ Advanced OECD economies used in calculations for long time series include Australia Canada, France, Germany, Japan, the Netherlands, the United Kingdom, and the United States; weighted using series on GDP at current U.S. dollars from the IMF's World Economic Outlook database.

${ }^{3}$ Advanced OECD economies used in calculations for short time series include Australia, Austria, Canada, Finland, France, Germany, Greece, Italy, the Netherlands, Japan, Korea, Portugal, Spain, Sweden, the United Kingdom, and the United States; weighted using series on GDP at current U.S. dollars from the IMF's World Economic Outlook database. 
Figure 7. Advanced Economies: Offshoring by Category of Inputs ${ }^{1}$

\begin{tabular}{l|l} 
Weighted average $\quad$ Range of country outcomes
\end{tabular}

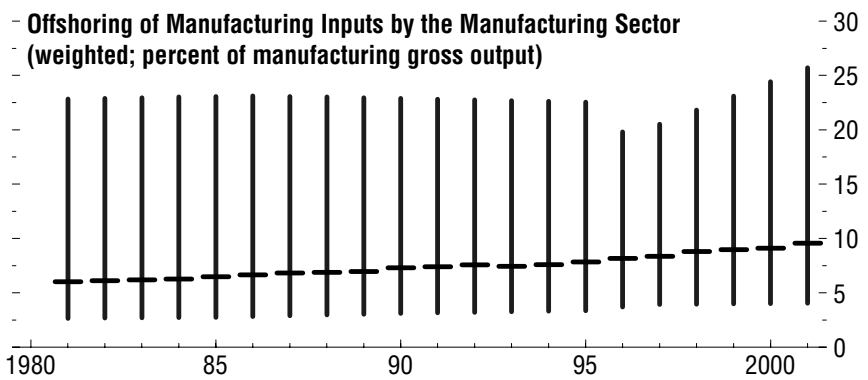

Offshoring of Services Inputs 2

(weighted; percent of gross output)

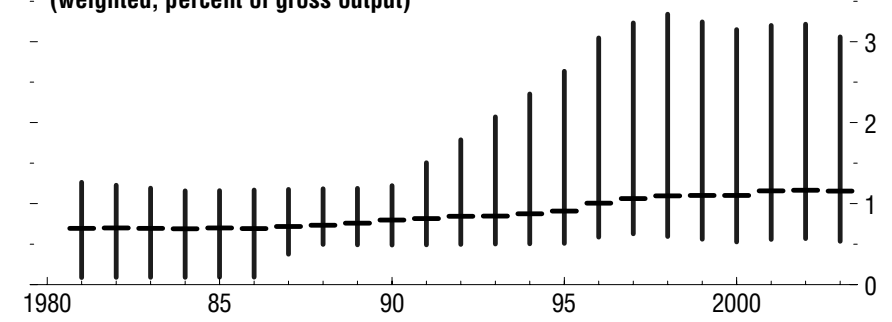

- Offshoring of Unskilled and Skilled Inputs (weighted; percent of gross output)

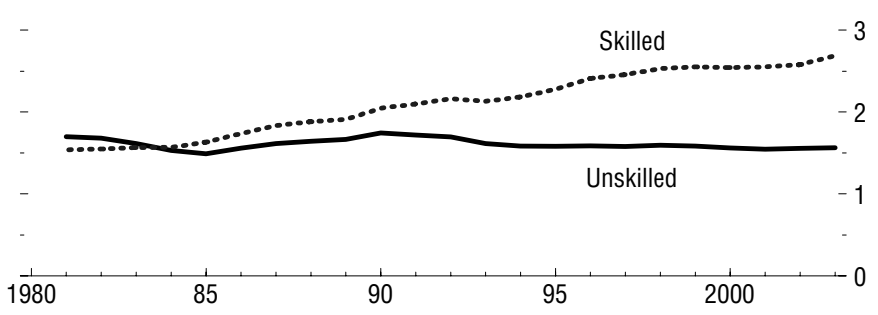

Sources: OECD, Input-Output Tables (1995, 2002, and 2006), International Trade in Services Database, and STAN Industrial Database; Groningen Growth and Development Centre, 60-Industry Database (September 2006); and IMF staff calculations.

${ }^{1}$ Offshoring measures calculated using Input-Output Tables from OECD; resulting series extended from 2001 to 2003 by estimating extent of offshoring using a combination of data from the OECD's STAN Industrial Database and the Groningen 60-Industry Database; only offshoring of nonenergy manufacturing and services inputs considered. Advanced OECD economies used in calculations for long time series include Australia, Canada, France, Germany, Japan, the Netherlands, the United Kingdom, and the United States; weighted using series on GDP at current U.S. dollars from the IMF's World Economic Outlook database.

2 Excludes the United States since import data are reported as inclusive of "cost, insurance, and freight"; thus, values that normally accrue to business services are included in associated goods sectors. 
Figure 8. Advanced Economies: Labor Income Shares (Percent of GDP unless otherwise noted)

— Income share of employees ${ }^{1} \quad \ldots$ Income share of labor ${ }^{2}$
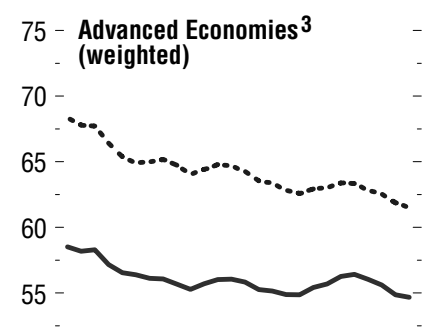

$50-$
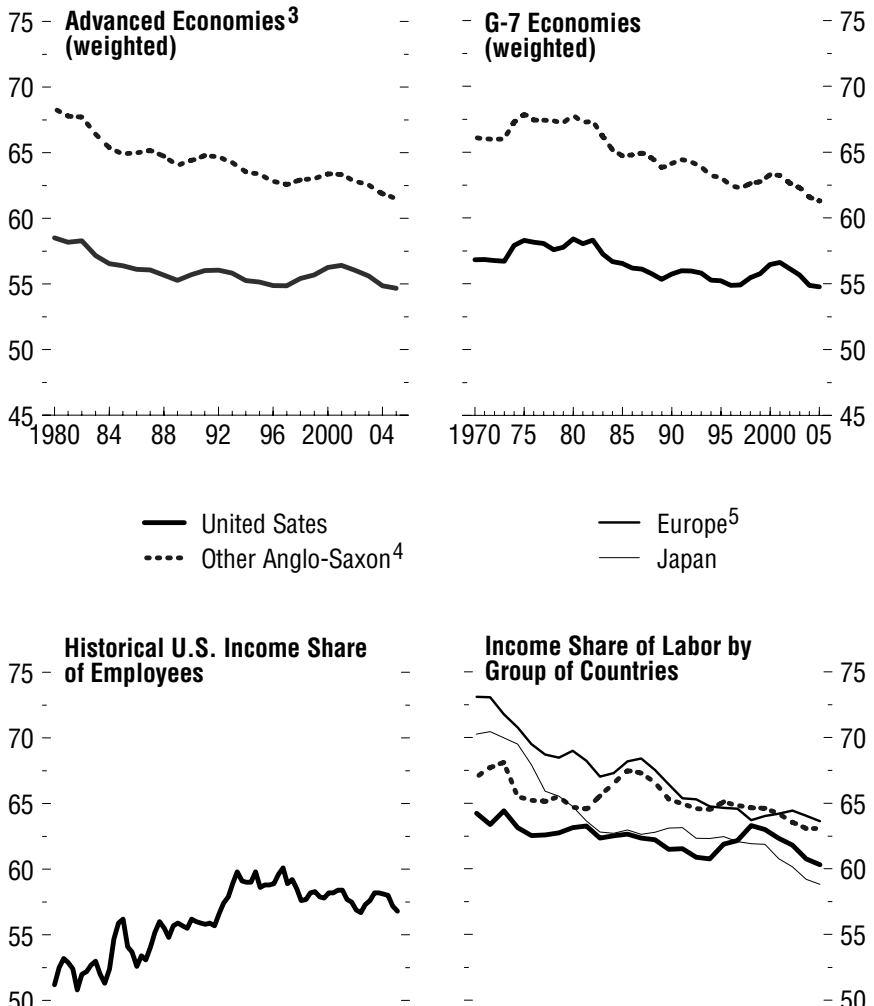

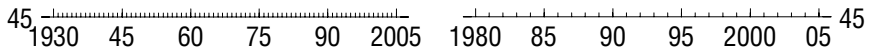




\section{Figure 8 (concluded)}

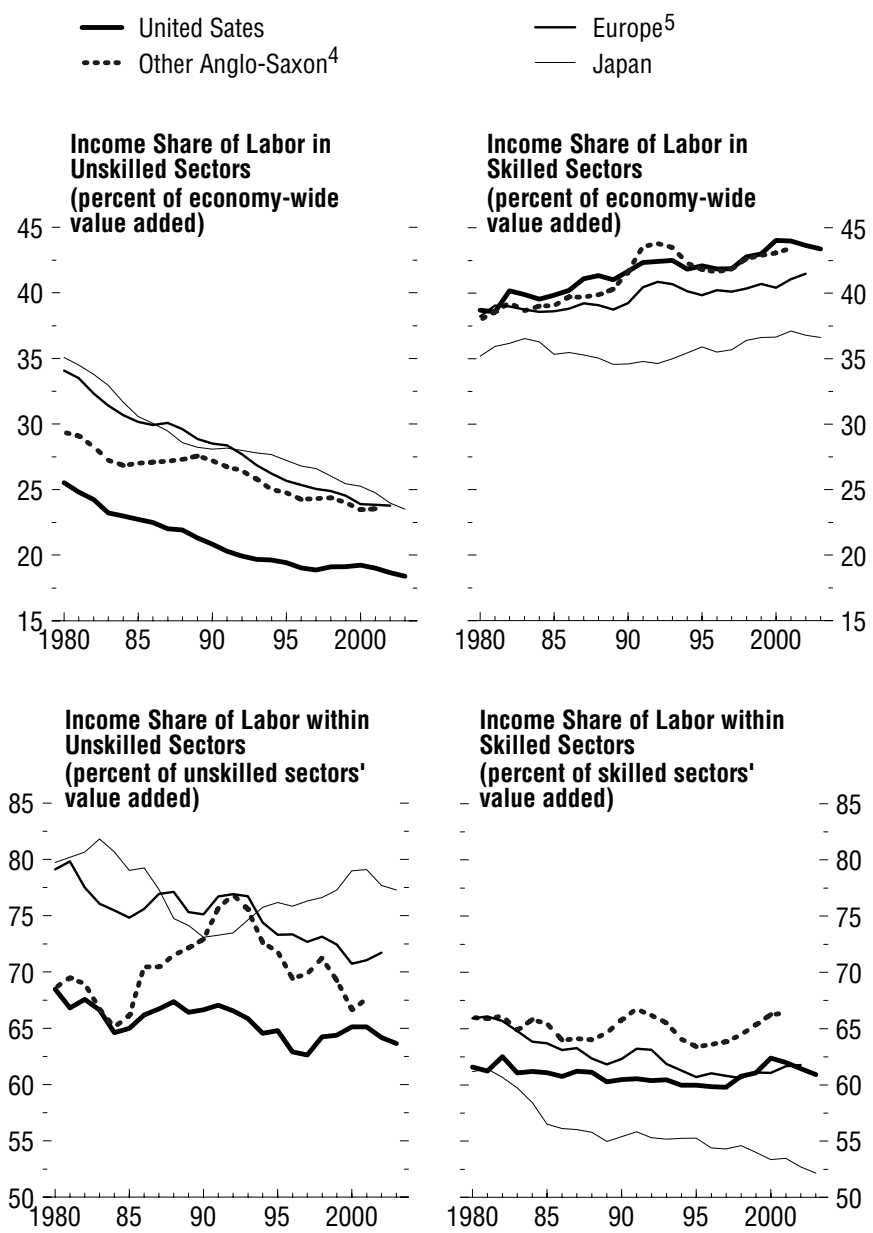

Sources: Haver Analytics; International Labor Organization, Labor Statistics Database; OECD, Employment and Labor Market Statistics, National Accounts Statistics, and STAN Industrial Database; United Nations, National Accounts Statistics (2004); and IMF staff calculations.

1 Income share of employees is the ratio of employees' labor compensation to value added.

2The income share of labor estimates the share of labor compensation of employees and "nonemployee" workers in value added.

${ }^{3}$ Advanced economies include Australia, Austria, Belgium, Canada, Denmark, Finland, France, Germany, Ireland, Italy, Japan, the Netherlands, Norway, Portugal, Spain, Sweden, the United Kingdom, and the United States; weighted using series on GDP in U.S. dollars from the IMF's World Economic Outlook database.

${ }^{4}$ Anglo-Saxon economies include Australia, Canada, and the United Kingdom. Australia is excluded from the analysis by skill level due to lack of data.

${ }^{5}$ Europe includes Austria, Belgium, Denmark, Finland, France, Germany, Ireland, Italy, the Netherlands, Norway, Portugal, Spain, and Sweden. Ireland, the Netherlands, and Spain are excluded from the analysis by skill level due to lack of data. 
Figure 9. Advanced Economies: Labor Compensation and Employment

$($ Index, 1980 = 100)

Real total labor compensation

Real labor compensation _ Employment per worker
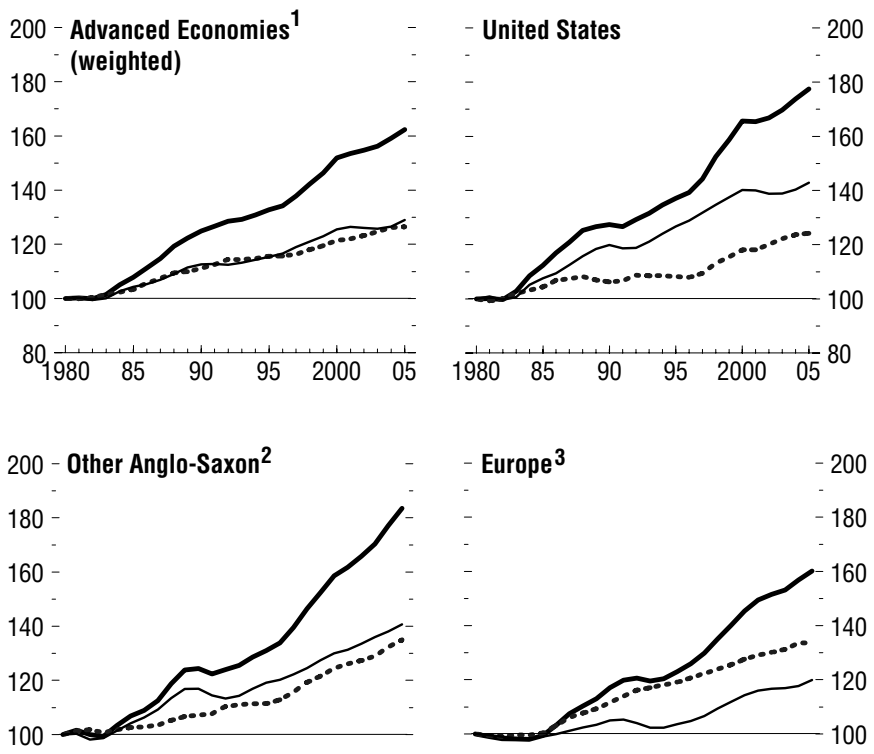

$\begin{array}{ll}\text { - Europe } & 3 \\ & -200\end{array}$
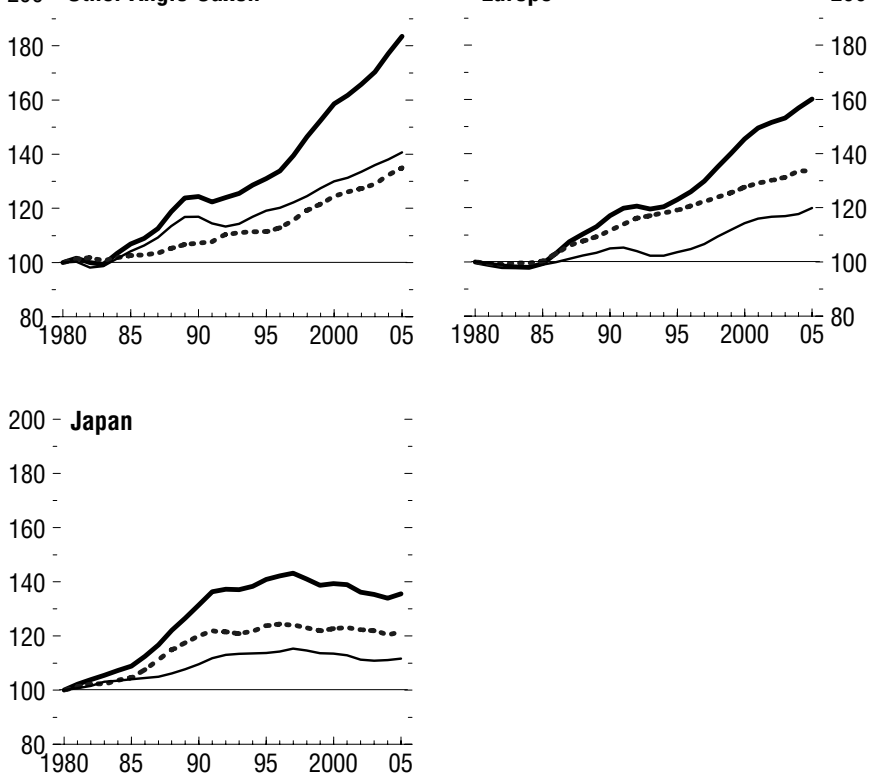

Sources: Haver Analytics; International Labor Organization, Labor Statistics Database; OECD, Employment and Labor Market Statistics, National Accounts Statistics, and STAN Industrial Database; United Nations, National Accounts Statistics (2004); and IMF staff calculations.

${ }^{1}$ Advanced economies include Australia, Austria, Belgium, Canada, Denmark, Finland, France, Germany, Ireland, Italy, Japan, the Netherlands, Norway, Portugal, Spain, Sweden, the United Kingdom, and the United States; weighted using series on GDP in U.S. dollars from the IMF's World Economic Outlook database.

${ }^{2}$ Anglo-Saxon economies include Australia, Canada, and the United Kingdom.

${ }^{3}$ Europe includes Austria, Belgium, Denmark, Finland, France, Germany, Ireland, Italy, the Netherlands, Norway, Portugal, Spain, and Sweden. 
Figure 10. Advanced Economies: Labor Compensation and Employment in Skilled and Unskilled Sectors

(Index, $1980=100)$

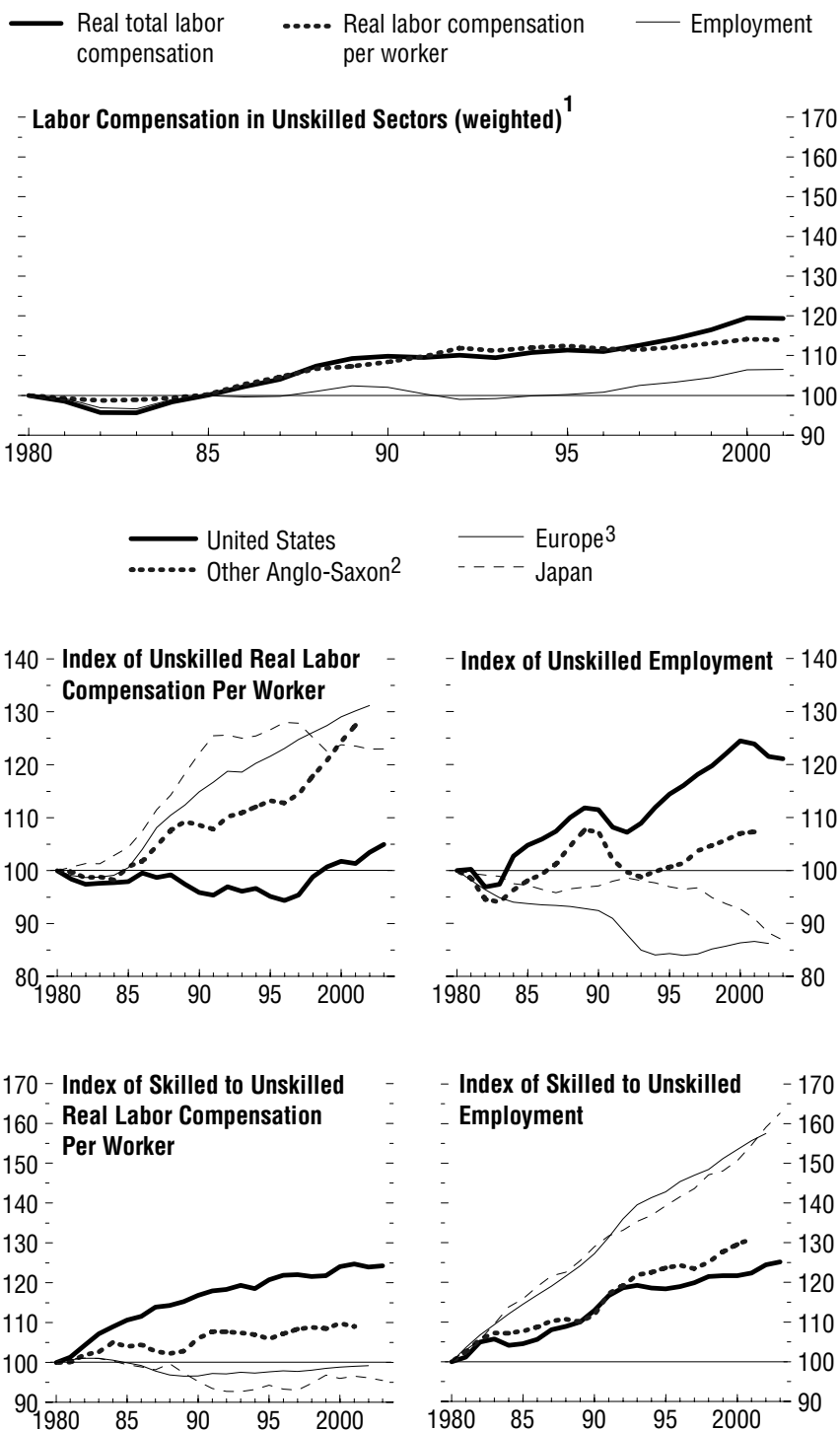

Sources: Haver Analytics; International Labor Organization, Labor Statistics Database; OECD, Employment and Labour Market Statistics, National Accounts Statistics, and STAN Industrial Database; United Nations, National Accounts Statistics (2004); and IMF staff calculations.

${ }^{1}$ For analysis by skill level, advanced economies include Austria, Belgium, Canada, Denmark, Finland, France, Germany, Italy, Japan, Norway, Portugal, Sweden, the United Kingdom, and the United States; weighted using series on GDP in U.S. dollars from the IMF's World Economic Outlook database.

${ }^{2}$ For analysis by skill level, Anglo-Saxon economies include Canada and the United Kingdom.

${ }^{3}$ For analysis by skill level, Europe includes Austria, Belgium, Denmark, Finland, France, Germany, Italy, Norway, Portugal, and Sweden. 
Figure 11. Catch-Up by Emerging Markets'

Manufacturing Wages

(Percent of U.S. manufacturing wages in constant PPP dollars)

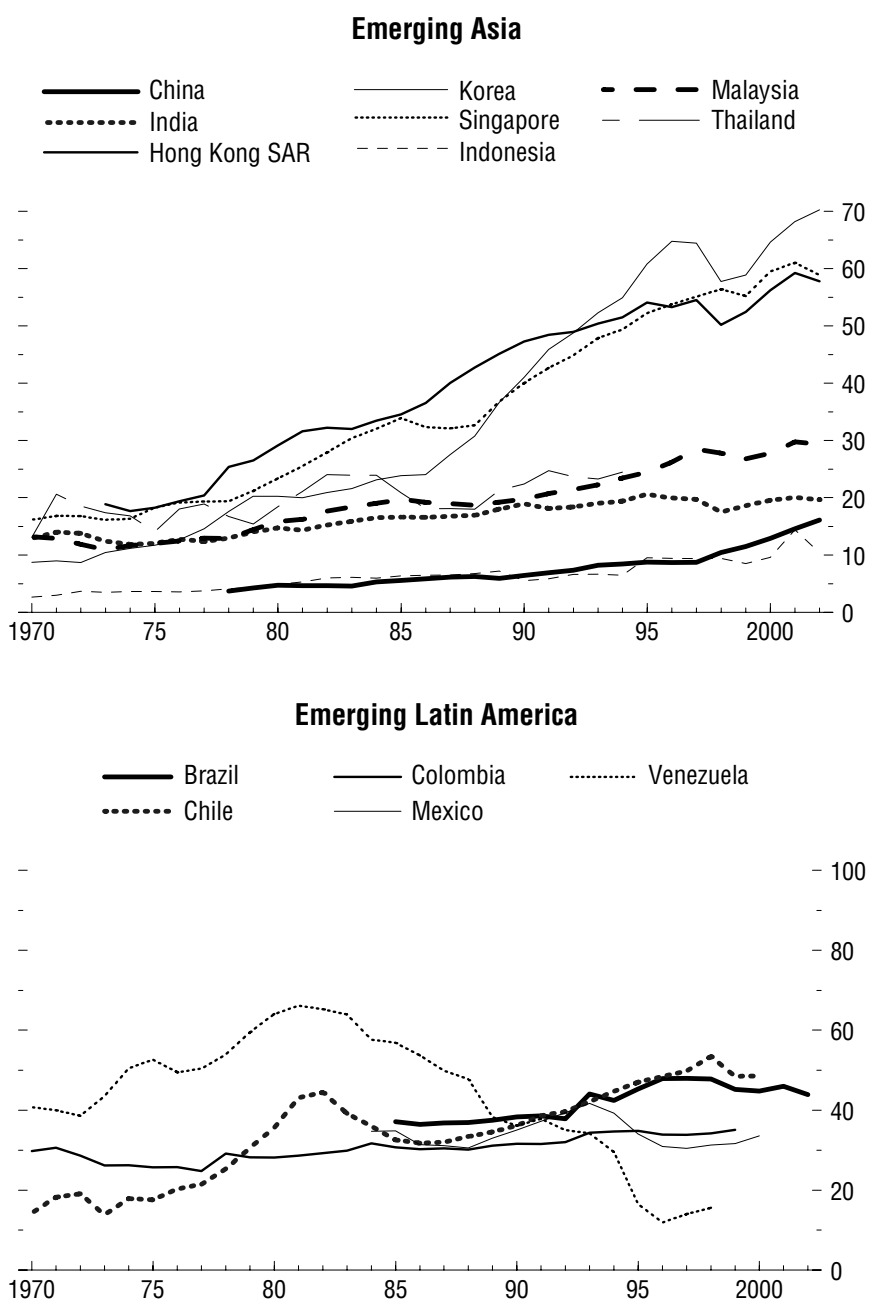

Sources: UNIDO, Industrial Statistics Database (2006); CEIC Asia Database; Instituto Brasileiro de Geografia e Estatística, Pesquisa Industrial Mensal; and IMF staff calculations. 
Figure 12. Information and Communications Technology (ICT) Capital, Patents, and Labor Market Indicators

- United States

.... Other Anglo-Saxon ${ }^{1}$

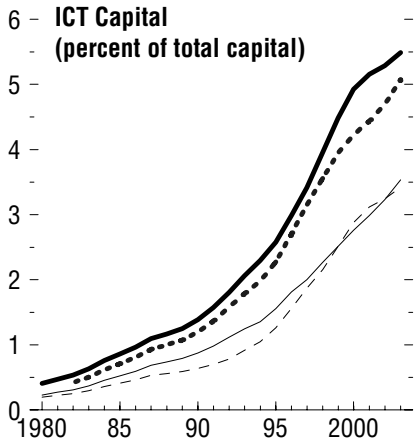

60 - Average Replacement Rate for Unemployment Benefits 50 - (percent of income)

40

30

20
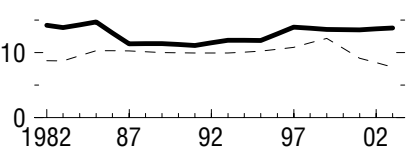

6 - Employment Protection Legislation Index

5 -

$4-$

$3-$

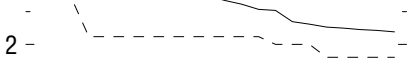

1

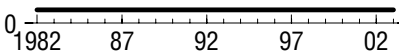

$$
\text { - Europe }{ }^{2}
$$

Number of Patents Per $\quad-180$

Working-Age Person ${ }^{3} \quad-160$

$-140$

$-120$

$-100$

$-80$

$-60$

$-40$

$-20$

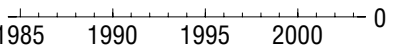

- Tax Wedge 4

$-60$

(percent of labor cost)

$-40$

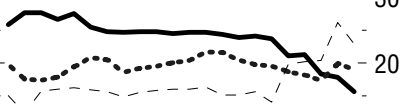

$-10$

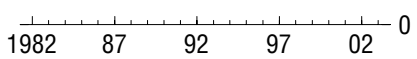

- Product Market Regulation Index - 6

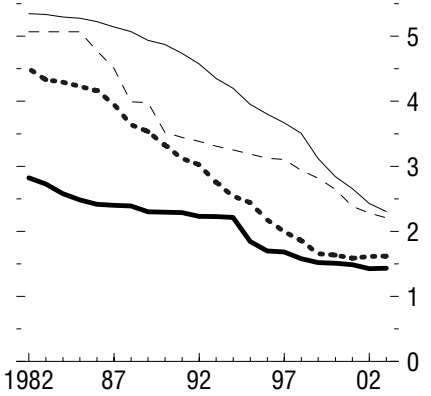

Sources: Bassanini and Duval (2006); Jorgenson and Vu (2005); OECD, Science and Technology Statistics; and IMF staff calculations.

1 Australia, Canada, New Zealand, and the United Kingdom.

${ }^{2}$ Austria, Belgium, Denmark, Finland, France, Germany, Ireland, Italy, the Netherlands, Norway, Portugal, Spain, Sweden, and Switzerland. Greece is not included due to data limitations.

3 Patents that have been filed at the European Patent Office, Japanese Patent Office, and granted by the United States Patent and Trademark Office (measured by priority year, that is, year of first application).

4 Difference between the labor cost to the employer and the net take-home pay of the employee, in percent of the labor cost. 
Figure 13. Partial Correlations
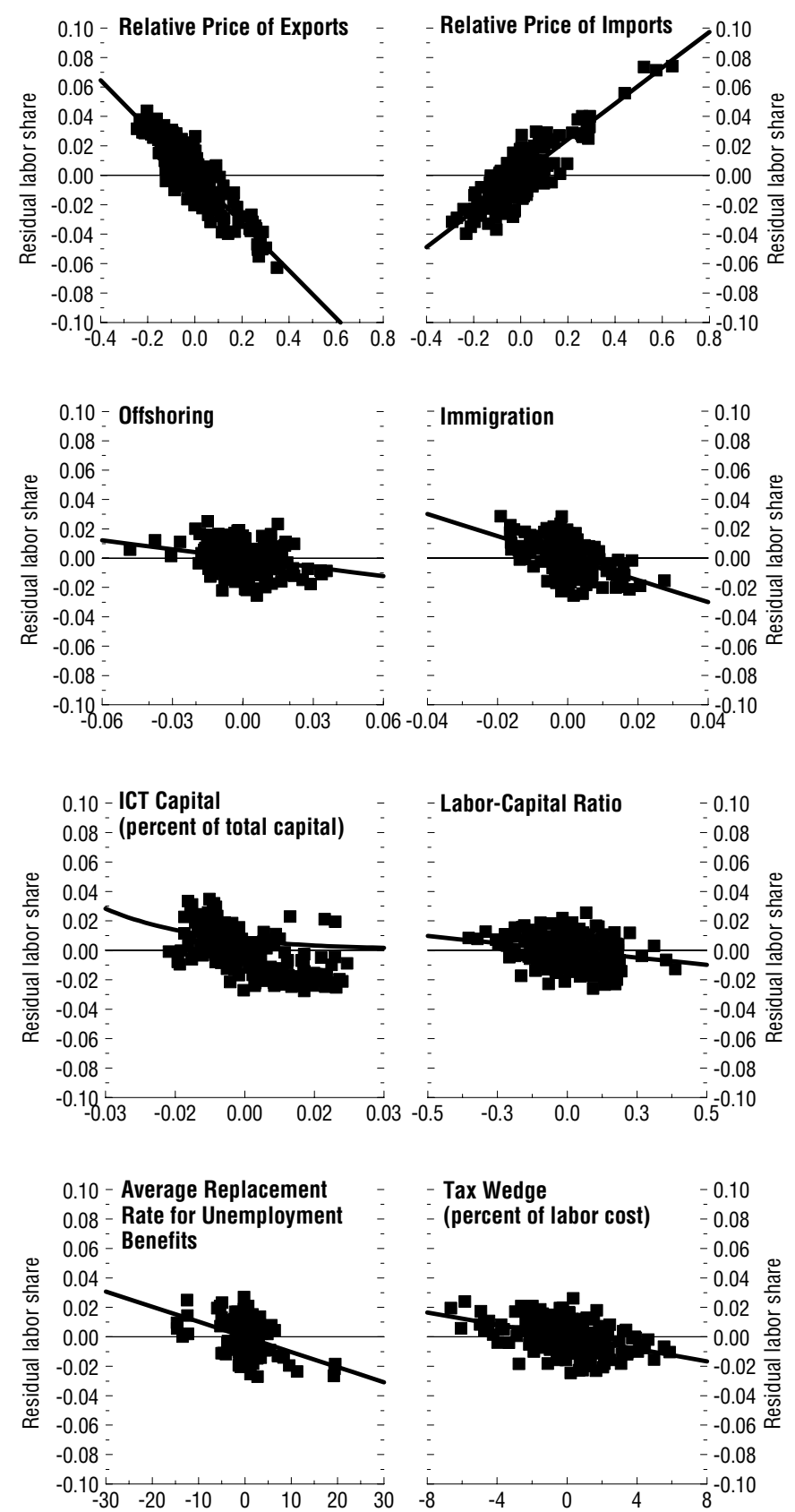

Source: IMF staff calculations.

${ }^{1}$ Correlation between the variable of interest (relative export or import price, offshoring, immigration, information and communications technology (ICT) capital, labor-capital ratio, unemployment benefits, and tax wedge) and residual labor share (i.e., labor share not explained by other regressors), based on the regression in column (4) of Table 1. 
Figure 14a. Explaining the Annual Change in the Labor Share ${ }^{1,2}$

(Average annual percent change)
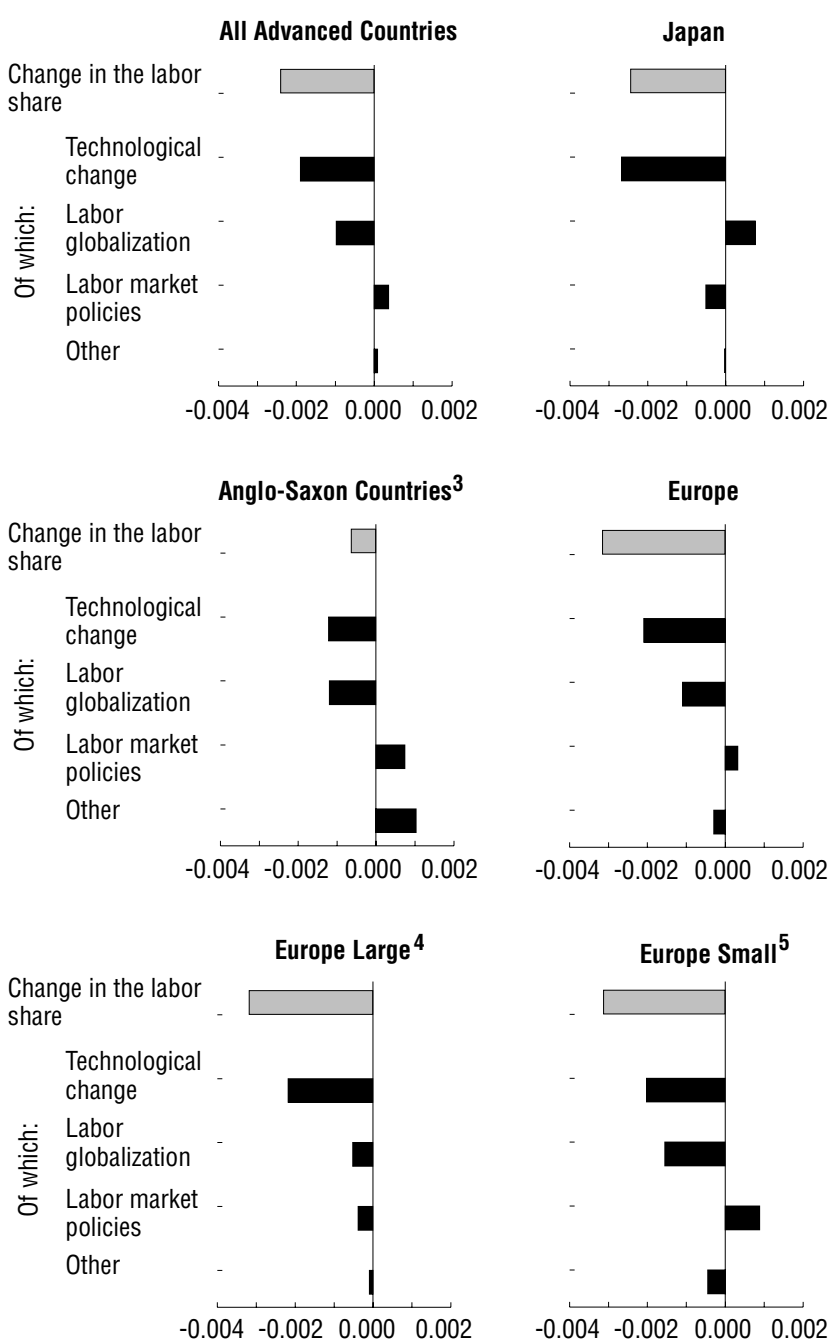

Source: IMF staff calculations.

1982-2002 or longest subperiod for which all variables used in the regression are available. 1986-2001 for Japan, as changes in the relative import price in earlier years reflected the yen's strong appreciation rather than globalization. The contribution of each variable is computed as the average annual change in the variable times the regression coefficient on the variable. The regression coefficients are taken from column (4) of Table 1.

${ }^{2}$ See Figure $14 \mathrm{~b}$ for the composition of the contribution of labor globalization. The contribution of other factors is the sum of the contributions of the labor-capital ratio, time dummies, and the residual.

${ }^{3}$ Anglo-Saxon countries include Australia, Canada, the United Kingdom, and the United States.

${ }^{4}$ Europe large includes France, Germany, Italy, and Spain

${ }^{5}$ Europe small covers Austria, Belgium, Denmark, Finland, Ireland, the Netherlands, Norway, Portugal, and Sweden. 
Figure 14b. Decomposition of Labor Globalization Effects on the Labor Share ${ }^{1}$

(Average annual percent change)
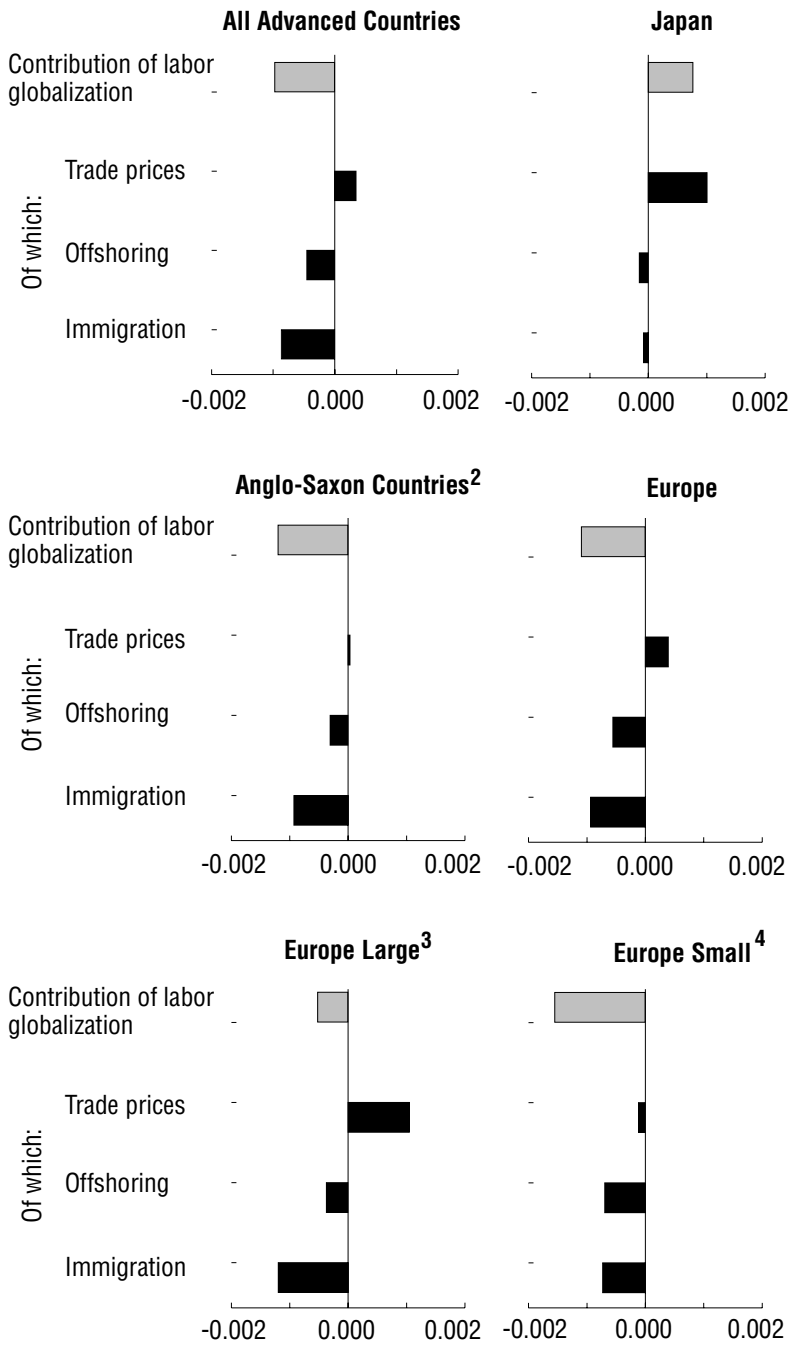

Source: IMF staff calculations.

11982-2002 or longest subperiod for which all variables used in the regression are available. 1986-2001 for Japan, as changes in the relative import price in earlier years reflected the yen's strong appreciation rather than globalization. The contribution of each variable is computed as the average annual change in the variable times the regression coefficient on the variable. The regression coefficients are taken from column (4) of Table 1.

${ }^{2}$ Anglo-Saxon countries include Australia, Canada, the United Kingdom, and the United States.

${ }^{3}$ Europe large includes France, Germany, Italy, and Spain

${ }^{4}$ Europe small covers Austria, Belgium, Denmark, Finland, Ireland, the Netherlands, Norway, Portugal, and Sweden. 
Figure 15. Explaining the Annual Change in the Labor Share by Skill Level ${ }^{1,2}$

(Average annual percent change)

\section{Skilled Sectors}

All Advanced Countries
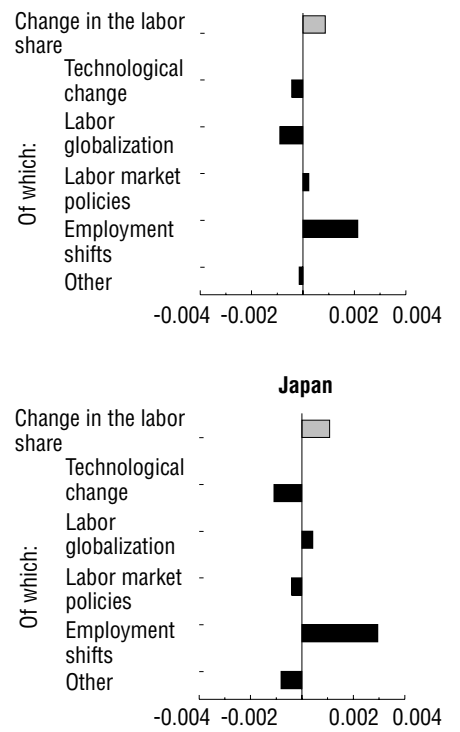

Anglo-Saxon Countries ${ }^{3}$

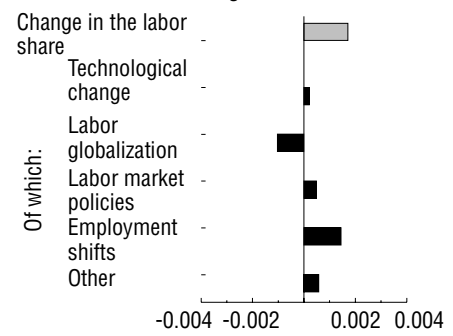

$-0.004-0.002$

\section{Unskilled Sectors}

All Advanced Countries
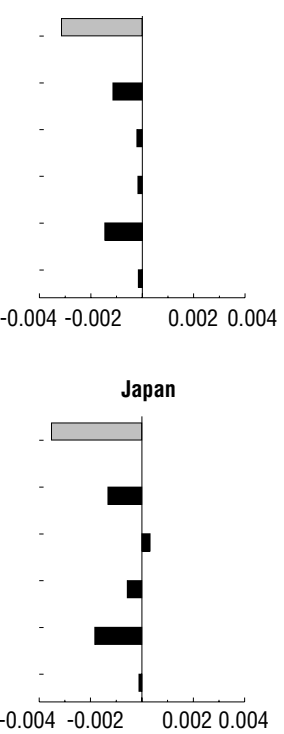

Anglo-Saxon Countries ${ }^{3}$
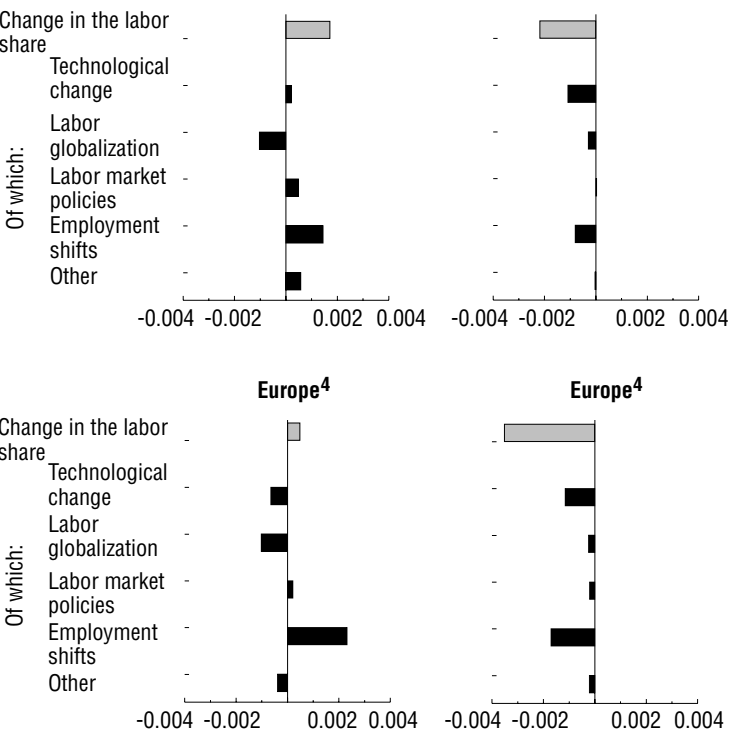

Source: IMF staff calculations.

1982-2002 or longest subperiod for which all variables used in the regression are available. 1986-2001 for Japan, as changes in the relative import price in earlier years reflected the yen's strong appreciation rather than globalization. The contribution of each variable is computed as the average annual change in the variable times the regression coefficient on the variable. The regression coefficients are taken from columns (3) and (4) of Table 3.

2The contribution of labor globalization is the sum of the contributions of trade prices, offshoring, and immigration. The contribution of other factors is the sum of the contributions of time dummies and the residual.

${ }^{3}$ Anglo-Saxon countries include Australia, Canada, the United Kingdom, and the United States.

4Europe includes Austria, Belgium, Denmark, Finland, France, Germany, Ireland, Italy, the Netherlands, Norway, Portugal, Spain, and Sweden. 


\section{Figure 16. Effect of Changes in Trade Prices on Labor Compensation per Worker and Employment ${ }^{1,2}$}

(Average annual percent change)

\section{Labor Compensation per Worker}

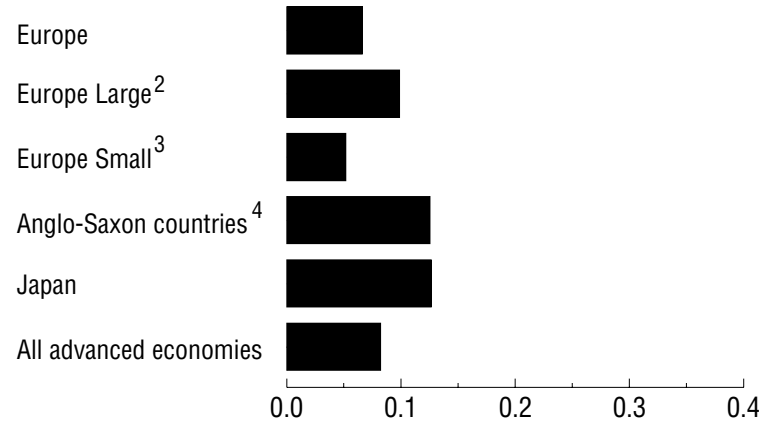

\section{Employment}

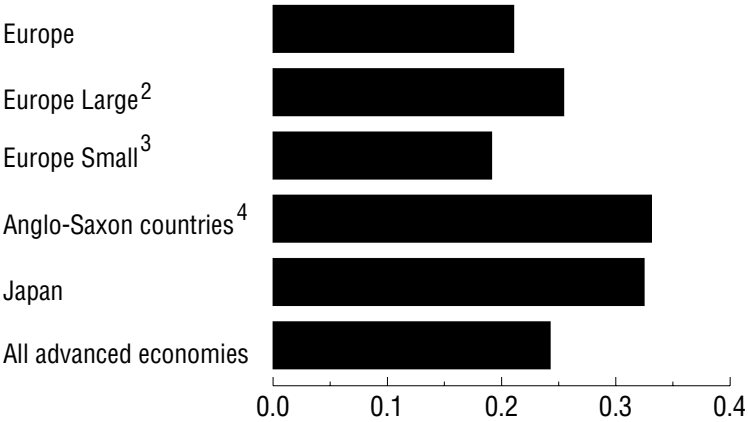

Source: IMF staff calculations.

11980-2004. 1986-2004 for Japan, as changes in the relative import price in earlier years reflected the yen's strong appreciation rather than globalization. The effects are based on the estimated regression coefficients in column (4) of Table 1 and average annual changes in relative trade prices in each country (see main text). The effect of changes in trade prices on labor compensation per worker assumes employment is fixed, and vice-versa.

2 Europe large includes France, Germany, Italy, and Spain.

3 Europe small covers Austria, Belgium, Denmark, Finland, Ireland, the Netherlands, Norway, Portugal, and Sweden.

${ }^{4}$ Anglo-Saxon countries include Australia, Canada, the United Kingdom, and the United States. 
Figure 17. Advanced Economies' Labor Income Share, Labor Compensation, and Employment: Robustness to Alternative Skill Classification ${ }^{1}$

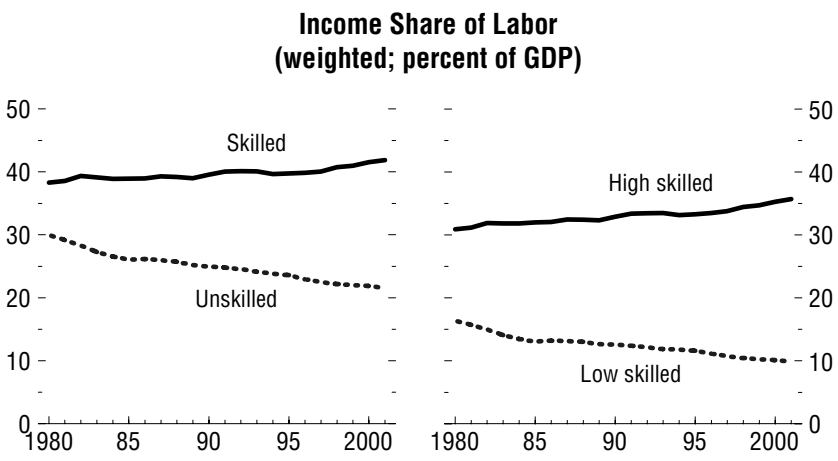

Real Labor Compensation Per Worker (weighted; index, $1980=100$ )

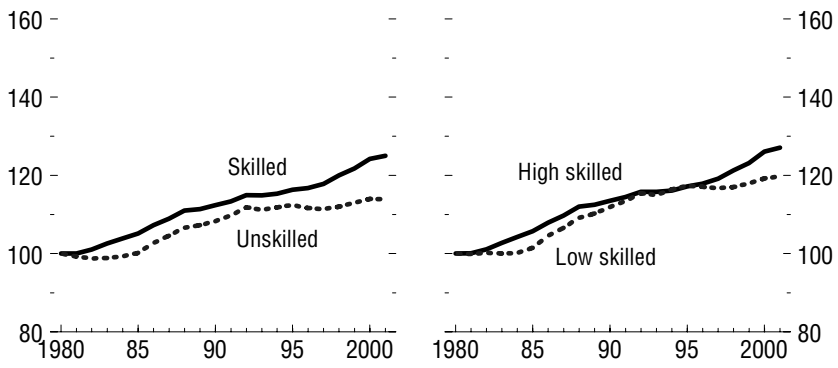

Employment

(weighted; index, $1980=100$ )

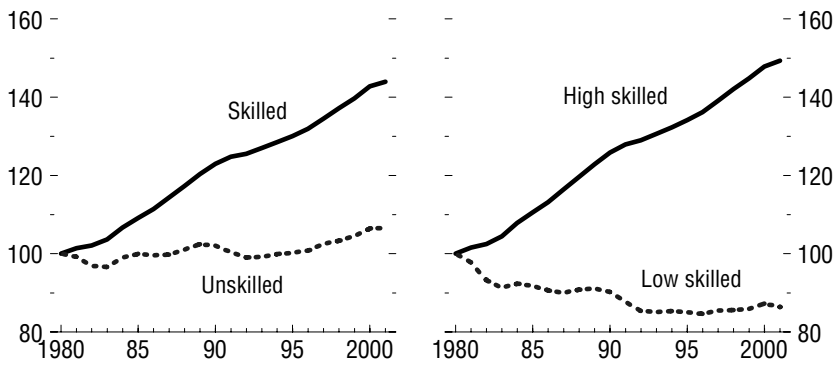

Sources: Haver Analytics; International Labor Organization, Labor Statistics Database; OECD, Employment and Labour Market Statistics, National Accounts Statistics, and STAN Industrial Database; United Nations, National Accounts Statistics (2004); and IMF staff calculations.

${ }^{1}$ For the analysis by skill level, advanced economies include Austria, Belgium, Canada, Denmark, Finland, France, Germany, Italy, Japan, Norway, Portugal, Sweden, the United Kingdom, and the United States; weighted using series on GDP in U.S. dollars from the IMF's World Economic Outlook database. 


\section{REFERENCES}

Amiti, Mary, and Shang-Jin Wei, 2005, “Fear of Service Outsourcing: Is It Justified?” Economic Policy, Vol. 20 (April), pp. 308-47.

— , 2006, "Service Offshoring and Productivity: Evidence from the United States," NBER Working Paper No. 11926 (Cambridge, Massachusetts: National Bureau of Economic Research).

Annett, Anthony, 2006, “Lessons from Successful Labor Market Reformers in Europe,” in Euro Area Policies: Selected Issues, IMF Country Report No. 06/288 (Washington: International Monetary Fund).

Barro, Robert J., and Jong-Wha Lee, 2000, “International Data on Educational Attainment: Updates and Implications,” CID Working Paper No. 42 (Cambridge, Massachusetts: Center for Global Development).

Bassanini, Andrea, and Romain Duval, 2006, "Employment Patterns in OECD Countries: Reassessing the Role of Policies and Institutions,” OECD Economics Department Working Paper No. 486 (Paris: Organization for Economic Cooperation and Development).

Berg, Andrew, and Anne O. Krueger, 2003, “Trade, Growth, and Poverty: A Selective Survey,” IMF Working Paper 03/30 (Washington: International Monetary Fund).

Blanchard, Olivier, 1998, "Revisiting European Unemployment: Unemployment, Capital Accumulation and Factor Prices,” NBER Working Paper No. 6566 (Cambridge, Massachusetts: National Bureau of Economic Research).

Blinder, Alan S., 2006, “Offshoring: The Next Industrial Revolution?” Foreign Affairs, Vol. 85 (March/April).

Christensen, Laurits R., Dale W. Jorgenson, and Lawrence J. Lau, 1975, “Transcendental Logarithmic Utility Functions,” American Economic Review, Vol. 65 (June), pp. 36783.

Conway, Paul, Donato de Rosa, Giuseppe Nicoletti, and Faye Steiner, 2006, "Regulation, Competition and Productivity Convergence,” OECD Economics Department Working Paper No. 509 (Paris: Organization for Economic Cooperation and Development).

Docquier, Frédéric, and Abdeslam Marfouk, 2005, “International Migration by Educational Attainment, 1990-2000,” in International Migration, Remittances and the Brain Drain, ed. by Ç. Özden and M. Schiff (Washington: World Bank). 
Fajnzylber, Pablo, and Daniel Lederman, 1999, "Economic Reforms and Total Factor Productivity Growth in Latin America and the Caribbean (1950-95)—An Empirical Note,” Policy Research Working Paper No. 2114 (Washington: World Bank).

Feenstra, Robert C., 2004, Advanced International Trade: Theory and Evidence (Princeton, New Jersey: Princeton University Press).

_ 2007, “Globalization and Its Impact on Labor,” Global Economy Lecture 2007, Vienna Institute for International Economic Studies, Vienna, February 8. Available via the Internet: http://www.econ.ucdavis.edu/faculty/fzfeens/papers.html

Freeman, Richard B., 1995, “Are Your Wages Set in Beijing?” Journal of Economic Perspectives, Vol. 9 (Summer), pp. 15-32.

—_, 2006, “Labor Market Imbalances: Shortages, or Surpluses, or Fish Stories?” paper presented at the Boston Federal Reserve Economic Conference, "Global Imbalances-As Giants Evolve,” Chatham, Massachusetts, June 14-16.

Gollin, Douglas, 2002, “Getting Income Shares Right,” Journal of Political Economy, Vol. 110 (April), pp. 458-74.

Greenwood, Michael J., Gary Hunt, and Ulrich Kohli, 1996, “The Short-Run and Long-Run Factor-Market Consequences of Immigration to the United States,” Journal of Regional Science, Vol. 36 (February), pp. 43-66.

Grossman, Gene M., and Esteban Rossi-Hansberg, 2006, “The Rise of Offshoring: It's Not Wine for Cloth Anymore,” paper presented at Federal Reserve Bank of Kansas City symposium, “The New Economic Geography: Effects and Policy Implications,” Jackson Hole, Wyoming, August 24-26. Available via the Internet: http://www.kc.frb.org/PUBLICAT/SYMPOS/2006/PDF/Grossmanand-RossiHansberg.paper.0831.pdf

Guscina, Anastasia, 2006, “Effects of Globalization on Labor’s Share in National Income,” IMF Working Paper 06/294 (Washington: International Monetary Fund).

Harrigan, James, 1998, “International Trade and American Wages in General Equilibrium, 1967-1995,” Staff Report No. 46 (New York: Federal Reserve Bank of New York).

— Prices, Technology, and Factor Supplies, 1963-1991,” NBER Working Paper No. 6981 (Cambridge, Massachusetts: National Bureau of Economic Research).

Harrison, Anne E., 2002, “Has Globalization Eroded Labor’s Share? Some Cross-Country Evidence,” (unpublished; Berkeley, California: University of California at Berkeley). 
International Monetary Fund, 2006, World Economic Outlook, September (Washington, D.C.).

— , 2007, World Economic Outlook, April (Washington, D.C.).

Jean, Sébastien, and Giuseppe Nicoletti, 2002, "Product Market Regulation and Wage Premia in Europe and North America: An Empirical Investigation,” OECD Economics Department Working Paper No. 318 (Paris: Organization for Economic Cooperation and Development).

Jensen, J. Bradford, and Lori G. Kletzer, 2005, “Tradable Services: Understanding the Scope and Impact of Services Outsourcing,” IIE Working Paper No. WP05-9 (Washington: Institute for International Economics).

Jorgenson, Dale W., and Khuong Vu, 2005, "Information Technology and the World Economy,” Scandinavian Journal of Economics, Vol. 107 (December), pp. 631-50.

Katz, Larry F., and David H. Autor, 1999, "Changes in the Wage Structure and Earnings Inequality," in Handbook of Labor Economics, Vol. 3A, ed. by Orley C. Ashenfelter and David Card (Amsterdam: North-Holland).

Kohli, Ulrich, 1991, Technology, Duality, and Foreign Trade: The GNP Function Approach to Modeling Imports and Exports (Ann Arbor: University of Michigan Press).

Lewer, Joshua J., and Hendrik Van den Berg, 2003, “How Large Is International Trade’s Effect on Economic Growth?” Journal of Economic Surveys, Vol. 17 (July), pp. 36396.

Nehru, Vikram, and Ashok Dhareshwar, 1993, "A New Database on Physical Capital Stock: Sources, Methodology, and Results,” Revista de Análisis Económico, Vol. 8, No. 1, pp. 37-59.

Organization for Economic Cooperation and Development (OECD), 2004, OECD Employment Outlook (Paris).

— , 2005, "Trade-Adjustment Costs in OECD Labour Markets: A Mountain or a Molehill?” in OECD Employment Outlook (Paris).

— , 2006a, “The Internationalisation of Production, International Outsourcing and OECD Labour Markets” (Paris).

— 2006b, "Migration in OECD Countries: Labour Market Impact and Integration Issues" (Paris).

Olsen, Karsten Bjerring, 2006, "Productivity Impacts of Offshoring and Outsourcing: A Review,” OECD Science, Technology and Industry Working Paper No. 2006/1 (Paris: Organization for Economic Cooperation and Development). 
Rodrik, Dani, 2006, “What’s So Special About China’s Exports?” NBER Working Paper No. 11947 (Cambridge, Massachusetts: National Bureau of Economic Research).

Slaughter, Matthew J., 2001, “International Trade and Labor-Demand Elasticities,” Journal of International Economics, Vol. 54 (June), pp. 27-56.

Tytell, Irina and Shang-Jin Wei, 2004, "Does Financial Globalization Induce Better Macroeconomic Policies?,” IMF Working Paper 04/84 (Washington: International Monetary Fund).

Young, Alwyn, 1995, “The Tyranny of Numbers: Confronting the Statistical Realities of the East Asian Growth Experience,” Quarterly Journal of Economics, Vol. 110 (August), pp. 641-80.

— 2003 , “Gold into Base Metals: Productivity Growth in the People’s Republic of China During the Reform Period,” Journal of Political Economy, Vol. 111 (December), pp. 1220-61.

World Bank, 2006, Global Economic Prospects 2007: Managing the Next Wave of Globalization (Washington). 